Westinghouse

Savannah River Company

Aiken, SC 29808

Savannah River Technology Center Immobilization Technology Section
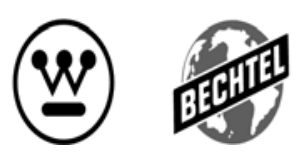

\#

BNFL

WSRC-TR-2002-00436

Page 1 of 34

\title{
Development of an Initial Simulant for the Idaho Tank Farm Solids (U)
}

John R. Harbour, Ray F. Schumacher, Alex Choi, and E. K. Hansen 
This document was prepared in conjunction with work accomplished under Contract No. DE-AC09-96SR18500 with the U. S. Department of Energy.

\section{DISCLAIMER}

This report was prepared as an account of work sponsored by an agency of the United States Government. Neither the United States Government nor any agency thereof, nor any of their employees, makes any warranty, express or implied, or assumes any legal liability or responsibility for the accuracy, completeness, or usefulness of any information, apparatus, product or process disclosed, or represents that its use would not infringe privately owned rights. Reference herein to any specific commercial product, process or service by trade name, trademark, manufacturer, or otherwise does not necessarily constitute or imply its endorsement, recommendation, or favoring by the United States Government or any agency thereof. The views and opinions of authors expressed herein do not necessarily state or reflect those of the United States Government or any agency thereof.

This report has been reproduced directly from the best available copy.

Available for sale to the public, in paper, from: U.S. Department of Commerce, National Technical Information Service, 5285 Port Royal Road, Springfield, VA 22161, phone: (800) 553-6847, fax: (703) 605-6900

email: orders@ntis.fedworld.gov

online ordering: http://www.ntis.gov/help/index.asp

Available electronically at http://www.osti.gov/bridge

Available for a processing fee to U.S. Department of Energy and its contractors, in paper, from: U.S. Department of Energy, Office of Scientific and Technical Information, P.O. Box 62, Oak Ridge, TN 37831-0062,

phone: (865)576-8401,

fax: (865)576-5728

email: $\underline{\text { reports@ adonis.osti.gov }}$ 
Savannah River Technology Center

Immobilization Technology Section

Approval Signatures:

Torn R Harbour

Author

J. R. Harbour

A.7. Schumacher

Author

R. F. Schumacher

Alchor

Author

A. S. Choi

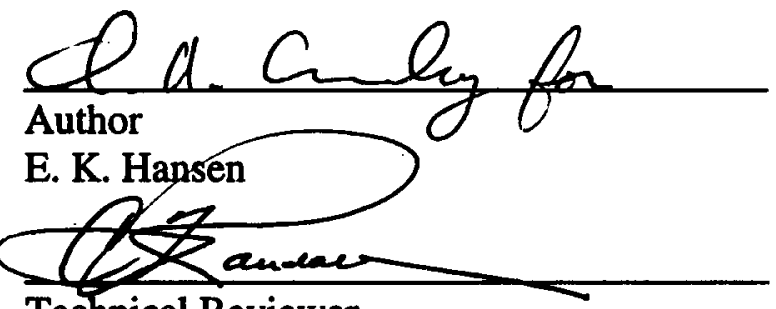

Technical Reviewer

C. T. Randall

eris

LevA 3 Manager, ITS

R.H. Spires

$\frac{\text { Quid. Ce by }}{\text { Level } 4 \text { Manager, ITS }}$

D. A. Crowley

EN thetzahutes

Level 3 Manager, ITS

E.W. Holtzscheiter
WSRC-TR-2002-00436

Page 2 of 34

November 11, 2002
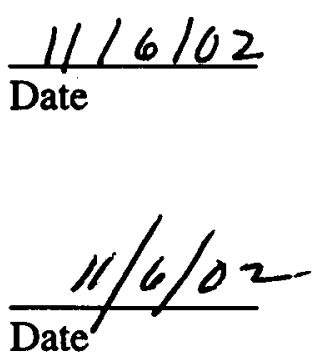

$\frac{11 / 6 / 02}{\text { Date }}$

$\frac{11 / 2 / 02}{\text { Date }}$

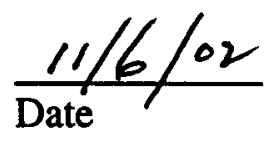

$\frac{11-8-02}{\text { Date }}$

$\frac{21 / 7 / 6-2}{\text { Date }}$

$\frac{11 / 8 / 02}{\text { Date }}$ 


\section{$\underline{\text { Summary and Conclusions }}$}

The goal of this task was to develop the methodology for producing a suitable simulant for waste solids and the fabrication of an initial simulant for use in the demonstrations and testing performed as part of the down-select process for disposition of INTEC tank waste. The analytical results from WM-182 and WM-183 tank samples were used as the basis for this work. Results included:

- An initial simulant (at two different acid concentrations) was developed, fabricated, and characterized. This simulant is a baseline simulant to which changes can be made as requirements are finalized and additional data (XRD and SEM on solids and results of 'washing' of the radioactive tank sample) obtained. Particle size distribution and rheology measurements were measured on the simulants.

- To develop the initial simulant, the chemical and radiochemical compositions of WM-182 and WM-183 insoluble solids were approximated by subtraction of the soluble solids from the total solids. The contribution of the soluble solids to the measured total solids was on the order of $30 \mathrm{wt} . \%$. This action removed the nitrate as a component of the insoluble solids. Charge balance was a problem due to the very high level of phosphate measured in the WM-183 solids. Calcium was added to balance the charges in this initial simulant.

- The calculations show that approximately half of the radioactivity from Tank WM183 total solids is associated with the soluble radionuclides in the supernate. On the other hand, only $10 \%$ of radioactivity from WM-182 total solids is associated with soluble radionuclides in the supernate.

- OLI/ESP modeling was applied to this system using the available supernate data for WM-183 and the solids data, modified to achieve charge balance, for WM-183. This model predicted solid species including silica, zirconia, and iron phosphate and also revealed issues with the high phosphate levels.

- A validation process is suggested and can be accomplished once simulant requirements are finalized and acceptance criteria established.

- A path forward is proposed that would lead to final simulants for the testing and demonstrations to be performed as part of the down-selection process. In particular, it is recommended that further studies with SEM and XRD using actual waste be performed to identify mineral phases present in the waste. Furthermore, it is recommended that a "washing" test be performed using actual sample(s) to determine the effect of washing on the physical and chemical properties of the solids. 


\section{Introduction}

Idaho is currently in a down-selection process to identify the technique that will be used to immobilize the solid and liquid phases of the Sodium Bearing Waste (SBW) contained in the INTEC Tank Farm. In order to properly evaluate and select a process, INEEL is planning a series of demonstrations and tests. The options being considered are (1) calcining a blend of liquid and solids, (2) steam reforming a blend of liquid and solids, (3) direct but separate evaporation of solids (in the form of sludge slurries) and liquids, and (4) cesium ion exchange followed by grouting of the eluant, or addition of silica gel to immobilize the liquid phase.

Because performing the down-select tests using actual waste is prohibitively expensive, it is critically important to develop and use waste simulants that realistically challenge the performance of the techniques being considered. Realistic simulants are important for evaluation of processing expectations, control of off-gas emissions, and compliance with waste form specifications. The liquid phase of SBW is well characterized and simulants have been developed that can be utilized during testing and demonstrations (1). However, the recent discovery of a significant amount of solids in the INTEC Tanks has required that a solid simulant also be developed for the SBW solids. A suitable simulant for solids has not yet been developed. This goal of this task is develop the methodology and produce an initial simulant for the solids for use in the demonstrations and testing performed as part of the down-select process.

In 1999, visual observation and sampling of the solids present in the 300,000-gallon WM-182 and WM-183 tanks were initiated (2,3). This study revealed that a layer of sludge exists at the bottom of both tanks. The sludge layer was about 8.5 inches high in WM-183 and about 4.5 inches high in WM-182. Estimates of sludge volumes in the other 8 tanks (WM-190 is empty) were also made. The final total estimate is $\sim 170,000$ liters of sludge in the ten tanks. Chemical and radionuclide analyses of the sludge samples from WM-182 and WM-183 were performed and the chemical composition and radionuclide inventory were determined for the two tanks. This new estimate of the amount, composition and nature of the sludge was different from the generally accepted position that the tanks contained a low percentage of undissolved solids (UDS).

The relatively large fraction of solids in the INTEC Tank Farm requires that the four options under consideration directly deal with the disposition of the solids. Therefore, a solid simulant must be developed for the upcoming demonstrations and testing.

The scope of the current task for developing a solid simulant involves the following activities:

1. Evaluation and analysis of the reported chemical composition (including RCRA metals) of the sludge samples from Tanks WM-182 and WM-183 and subtraction of components contained in the interstitial supernate. 
2. Evaluation and analysis of the reported radionuclide composition of the sludge samples from Tanks WM-182 and WM-183 and subtraction of the radionuclide components contained in the interstitial supernate.

3. Determine the viability of OLI modeling to predict solid phases.

4. Identification of the type of waste form (LLW, TRU etc.) produced for each of the four options and the corresponding disposal facility to which it will be sent (e.g., WIPP, RWMC, Hanford, Envirocare, and NTS).

5. Understanding simulant requirements based on the process flow diagrams for each option and on operations to remove and transfer solids from the tanks.

6. Identify an initial set of simulant requirements using existing data.

7. Develop an initial simulant based on existing data.

8. Define a path forward for final simulant development.

9. Identify potential data needs to develop the final simulant.

10. Identify and develop a strategy for simulant validation.

\section{Background on Solids Removal and Transfer}

Removal of the liquid SBW from each tank will result in a layer of sludge at the tank bottom. This sludge will eventually be transferred to Tank WM-187 and will be pumped from this tank as needed for processing (four options at this time). It is estimated that removal and transfer from each tank will require 100,000 gallons of water. For example, the contents of WM-183 will be transferred to Tank WM-187 along with 100,000 gallons of water. The solids in Tank WM-187 will then be allowed to settle, and the liquid removed using steam jets to another tank. This process has the effect of washing of the solids to remove substantial quantities of salts dissolved in the interstitial supernate. (E.g., Idaho (2) has determined that $75 \%$ of the volume of the sludge in WM-183 is due to liquid supernate.) The sequence and timing of the processing will depend on the option selected, but it is clear that WM-187 may contain a mixture of various tank solids at any one time.

It is further been estimated that $\sim 200,000$ gallons of water will be required to remove the solids from Tank WM-187 and transport it to the processing location. Therefore, the sludge will undergo a second "washing" due to these transfers. It is not clear how many transfers will actually occur but the estimate is for a total of 200,000 gallons for all transfers.

The solids as they exist in the highly acidic tanks may change as washing occurs through transfer. In fact, the acidity will drop significantly as the supernate is removed from the solids. Dissolution or precipitation reactions can occur during this washing/transfer step changing the composition of the solid and liquid phases that comprise the waste as well as the properties of the waste. Consequently, the simulant requirements (both the physical and chemical) for processing may be different than the measured properties of the tank samples in the highly acidic medium. This data is currently not available. 


\section{Evaluation and Analysis of the Reported Chemical Compositions for WM-182 and $\underline{\text { WM-183 Solids }}$}

Total Solids. The chemical compositions of sludge samples taken from WM-182 and WM-183 have been determined by INEEL $(2,3)$. The major components of the air-dried solids are presented in Table 1. The corresponding results for RCRA metals present in these solid samples are presented in Table 2 .

From columns 2 and 3 of Table 1 it is noted that only $41 \%$ of the sample from WM-182 and $47 \%$ of the sample from WM- 183 is accounted for. The undetermined amounts are presumably due to oxygen bound in oxides and residual water that is either present as waters of hydration or free water.

Table 1 -Major Chemical Species in Air-Dried Sludge Samples from Tanks WM182 and WM-183 (Measurements of $\mathrm{mg} / \mathrm{kg}$ by INEEL)

\begin{tabular}{|c|c|c|c|c|c|}
\hline Species & $\mathbf{W M - 1 8 2}$ & $\mathbf{W M - 1 8 3}$ & Atomic/ & Moles/kg & Moles/kg \\
\hline & $\mathbf{m g} / \mathbf{k g}$ & $\mathbf{m g} / \mathbf{k g}$ & Molecular Wt & WM-182 & WM-183 \\
\hline $\mathbf{A l}$ & $2.19 \mathrm{E}+04$ & $2.49 \mathrm{E}+04$ & 26.98 & $8.12 \mathrm{E}-01$ & $9.23 \mathrm{E}-01$ \\
\hline $\mathbf{B}$ & $1.50 \mathrm{E}+02$ & $1.82 \mathrm{E}+02$ & 10.81 & $1.39 \mathrm{E}-02$ & $1.68 \mathrm{E}-02$ \\
\hline $\mathbf{C a}$ & $1.77 \mathrm{E}+03$ & $1.87 \mathrm{E}+03$ & 40.08 & $4.42 \mathrm{E}-02$ & $4.67 \mathrm{E}-02$ \\
\hline $\mathbf{F e}$ & $4.48 \mathrm{E}+03$ & $1.80 \mathrm{E}+04$ & 55.85 & $8.02 \mathrm{E}-02$ & $3.22 \mathrm{E}-01$ \\
\hline $\mathbf{K}$ & $7.05 \mathrm{E}+03$ & $1.09 \mathrm{E}+04$ & 39.10 & $1.80 \mathrm{E}-01$ & $2.79 \mathrm{E}-01$ \\
\hline $\mathbf{M g}$ & $4.10 \mathrm{E}+02$ & $4.34 \mathrm{E}+02$ & 24.31 & $1.69 \mathrm{E}-02$ & $1.79 \mathrm{E}-02$ \\
\hline $\mathbf{M n}$ & $5.65 \mathrm{E}+02$ & $7.40 \mathrm{E}+02$ & 54.94 & $1.03 \mathrm{E}-02$ & $1.35 \mathrm{E}-02$ \\
\hline $\mathbf{M o}$ & $2.50 \mathrm{E}+03$ & $6.94 \mathrm{E}+02$ & 95.94 & $2.60 \mathrm{E}-02$ & $7.23 \mathrm{E}-03$ \\
\hline $\mathbf{N b}$ & $1.28 \mathrm{E}+03$ & $6.23 \mathrm{E}+02$ & 92.91 & $1.38 \mathrm{E}-02$ & $6.71 \mathrm{E}-03$ \\
\hline $\mathbf{S i}$ & $4.39 \mathrm{E}+04$ & $3.53 \mathrm{E}+04$ & 28.09 & $1.56 \mathrm{E}+00$ & $1.26 \mathrm{E}+00$ \\
\hline $\mathbf{N a}$ & $3.04 \mathrm{E}+04$ & $2.14 \mathrm{E}+04$ & 22.99 & $1.32 \mathrm{E}+00$ & $9.31 \mathrm{E}-01$ \\
\hline $\mathbf{S n}$ & $4.07 \mathrm{E}+03$ & $1.47 \mathrm{E}+03$ & 118.71 & $3.43 \mathrm{E}-02$ & $1.24 \mathrm{E}-02$ \\
\hline $\mathbf{T i}$ & $6.50 \mathrm{E}+02$ & $7.11 \mathrm{E}+02$ & 47.87 & $1.36 \mathrm{E}-02$ & $1.49 \mathrm{E}-02$ \\
\hline $\mathbf{Z r}$ & $1.01 \mathrm{E}+05$ & $3.49 \mathrm{E}+04$ & 91.22 & $1.11 \mathrm{E}+00$ & $3.83 \mathrm{E}-01$ \\
\hline $\mathbf{C l}$ & $2.02 \mathrm{E}+03$ & $1.31 \mathrm{E}+03$ & 35.45 & $5.70 \mathrm{E}-02$ & $3.70 \mathrm{E}-02$ \\
\hline $\mathbf{F}$ & $1.48 \mathrm{E}+04$ & $4.37 \mathrm{E}+03$ & 19.00 & $7.79 \mathrm{E}-01$ & $2.30 \mathrm{E}-01$ \\
\hline $\mathbf{N O}{ }_{3}$ & $7.07 \mathrm{E}+04$ & $1.75 \mathrm{E}+05$ & 62.01 & $1.14 \mathrm{E}+00$ & $2.82 \mathrm{E}+00$ \\
\hline $\mathbf{P O}_{\mathbf{4}}$ & $6.84 \mathrm{E}+04$ & $1.26 \mathrm{E}+05$ & 94.97 & $7.20 \mathrm{E}-01$ & $1.33 \mathrm{E}+00$ \\
\hline $\mathbf{S O}_{\mathbf{4}}$ & $3.32 \mathrm{E}+04$ & $1.36 \mathrm{E}+04$ & 96.07 & $3.46 \mathrm{E}-01$ & $1.42 \mathrm{E}-01$ \\
\hline $\mathbf{T O T A L}$ & $\mathbf{4 . 0 9 E + 0 5}$ & $\mathbf{4 . 7 2 E + 0 5}$ & & $\mathbf{8 . 2 8 E}+00$ & $\mathbf{8 . 7 9 E + 0 0}$ \\
\hline
\end{tabular}


Table 2 -RCRA Metals in Air-Dried Sludge Samples from Tanks WM-182 and WM-183 (Measurements of mg/kg by INEEL).

\begin{tabular}{|c|c|c|c|c|}
\hline & $\mathbf{W M - 1 8 2}$ & $\mathbf{W M - 1 8 3}$ & $\mathbf{W M - 1 8 2}$ & $\mathbf{W M - 1 8 3}$ \\
\hline & $\mathbf{m g} / \mathbf{k g}$ & $\mathbf{m g} / \mathbf{k g}$ & $\mathbf{m o l e s} / \mathbf{k g}$ & $\mathbf{m o l e s} / \mathbf{k g}$ \\
\hline $\mathbf{S b}$ & $1.40 \mathrm{E}+01$ & $3.20 \mathrm{E}+01$ & $1.15 \mathrm{E}-04$ & $2.63 \mathrm{E}-04$ \\
\hline $\mathbf{A s}$ & $2.81 \mathrm{E}+02$ & $5.60 \mathrm{E}+01$ & $3.75 \mathrm{E}-03$ & $7.47 \mathrm{E}-04$ \\
\hline $\mathbf{B a}$ & $1.27 \mathrm{E}+02$ & $2.40 \mathrm{E}+01$ & $9.25 \mathrm{E}-04$ & $1.75 \mathrm{E}-04$ \\
\hline $\mathbf{C d}$ & $3.25 \mathrm{E}+02$ & $1.42 \mathrm{E}+02$ & $2.89 \mathrm{E}-03$ & $1.26 \mathrm{E}-03$ \\
\hline $\mathbf{C r}$ & $5.52 \mathrm{E}+02$ & $9.49 \mathrm{E}+02$ & $1.06 \mathrm{E}-02$ & $1.83 \mathrm{E}-02$ \\
\hline $\mathbf{P b}$ & $3.69 \mathrm{E}+02$ & $2.74 \mathrm{E}+02$ & $1.78 \mathrm{E}-03$ & $1.32 \mathrm{E}-03$ \\
\hline $\mathbf{H g}$ & $3.10 \mathrm{E}+02$ & $3.24 \mathrm{E}+02$ & $1.55 \mathrm{E}-03$ & $1.62 \mathrm{E}-03$ \\
\hline $\mathbf{N i}$ & $3.09 \mathrm{E}+02$ & $4.17 \mathrm{E}+02$ & $5.26 \mathrm{E}-03$ & $7.10 \mathrm{E}-03$ \\
\hline $\mathbf{S e}$ & $9.10 \mathrm{E}+01$ & $1.30 \mathrm{E}+01$ & $1.15 \mathrm{E}-03$ & $1.65 \mathrm{E}-04$ \\
\hline $\mathbf{A g}$ & $6.50 \mathrm{E}+01$ & $2.20 \mathrm{E}+02$ & $6.03 \mathrm{E}-04$ & $2.04 \mathrm{E}-03$ \\
\hline $\mathbf{Z n}$ & $1.79 \mathrm{E}+02$ & $1.48 \mathrm{E}+02$ & $2.74 \mathrm{E}-03$ & $2.26 \mathrm{E}-03$ \\
\hline
\end{tabular}

Supernate. The chemical compositions of the supernate samples taken from WM-182 and WM-183 have been determined by INEEL(4). The major components of these samples are presented in Table 3. The corresponding results for RCRA metals present in these solid samples are presented in Table 4.

Table 3 -Major Chemical Species in Supernate Samples from Tanks WM-182 and WM-183 (Measurements by INEEL).

\begin{tabular}{|c|c|c|c|c|c|}
\hline Species & $\mathbf{W M - 1 8 2}$ & $\mathbf{W M - 1 8 3}$ & Atomic/ & Moles/kg & Moles/kg \\
\hline & $\mathbf{m g} / \mathbf{k g}$ & $\mathbf{~ m g / k g}$ & Molecular Wt & $\mathbf{W M - 1 8 2}$ & $\mathbf{W M - 1 8 3}$ \\
\hline $\mathbf{A l}$ & $7.11 \mathrm{E}+03$ & $9.67 \mathrm{E}+03$ & 26.98 & $2.64 \mathrm{E}-01$ & $3.58 \mathrm{E}-01$ \\
\hline $\mathbf{B}$ & $4.13 \mathrm{E}+01$ & $8.11 \mathrm{E}+01$ & 10.81 & $3.82 \mathrm{E}-03$ & $7.50 \mathrm{E}-03$ \\
\hline $\mathbf{C a}$ & $4.74 \mathrm{E}+02$ & $8.68 \mathrm{E}+02$ & 40.08 & $1.18 \mathrm{E}-02$ & $2.17 \mathrm{E}-02$ \\
\hline $\mathbf{F e}$ & $5.58 \mathrm{E}+02$ & $1.58 \mathrm{E}+03$ & 55.85 & $1.00 \mathrm{E}-02$ & $2.83 \mathrm{E}-02$ \\
\hline $\mathbf{K}$ & $1.81 \mathrm{E}+03$ & $2.25 \mathrm{E}+03$ & 39.10 & $4.64 \mathrm{E}-02$ & $5.75 \mathrm{E}-02$ \\
\hline $\mathbf{M g}$ & $6.85 \mathrm{E}+01$ & $1.62 \mathrm{E}+02$ & 24.31 & $2.82 \mathrm{E}-03$ & $6.67 \mathrm{E}-03$ \\
\hline $\mathbf{M n}$ & $2.10 \mathrm{E}+02$ & $3.75 \mathrm{E}+02$ & 54.94 & $3.82 \mathrm{E}-03$ & $6.83 \mathrm{E}-03$ \\
\hline $\mathbf{M o}$ & $1.22 \mathrm{E}+01$ & $4.48 \mathrm{E}+01$ & 95.94 & $1.27 \mathrm{E}-04$ & $4.67 \mathrm{E}-04$ \\
\hline $\mathbf{N b}$ & $8.78 \mathrm{E}-01$ & $3.72 \mathrm{E}+00$ & 92.91 & $9.45 \mathrm{E}-06$ & $4.00 \mathrm{E}-05$ \\
\hline $\mathbf{S i}$ & $3.06 \mathrm{E}+01$ & $7.49 \mathrm{E}+01$ & 28.09 & $1.09 \mathrm{E}-03$ & $2.67 \mathrm{E}-03$ \\
\hline $\mathbf{N a}$ & $8.99 \mathrm{E}+03$ & $1.05 \mathrm{E}+04$ & 22.99 & $3.91 \mathrm{E}-01$ & $4.58 \mathrm{E}-01$ \\
\hline $\mathbf{S n}$ & $1.08 \mathrm{E}+00$ & $1.09 \mathrm{E}+00$ & 118.71 & $9.09 \mathrm{E}-06$ & $9.17 \mathrm{E}-06$ \\
\hline $\mathbf{T i}$ & $9.57 \mathrm{E}-01$ & $1.91 \mathrm{E}+00$ & 47.87 & $2.00 \mathrm{E}-05$ & $4.00 \mathrm{E}-05$ \\
\hline $\mathbf{Z r}$ & $1.24 \mathrm{E}+02$ & $8.36 \mathrm{E}+01$ & 91.22 & $1.36 \mathrm{E}-03$ & $9.17 \mathrm{E}-04$ \\
\hline $\mathbf{C l}$ & $2.68 \mathrm{E}+02$ & $2.42 \mathrm{E}+02$ & 35.45 & $7.55 \mathrm{E}-03$ & $6.83 \mathrm{E}-03$ \\
\hline $\mathbf{F}$ & $5.53 \mathrm{E}+02$ & $5.86 \mathrm{E}+02$ & 19.00 & $2.91 \mathrm{E}-02$ & $3.08 \mathrm{E}-02$ \\
\hline $\mathbf{N O}{ }_{3}$ & $7.89 \mathrm{E}+04$ & $1.45 \mathrm{E}+05$ & 62.01 & $1.27 \mathrm{E}+00$ & $2.33 \mathrm{E}+00$ \\
\hline $\mathbf{P O}_{\mathbf{4}}$ & $2.55 \mathrm{E}+01$ & $2.37 \mathrm{E}+01$ & 94.97 & $2.68 \mathrm{E}-04$ & $2.49 \mathrm{E}-04$ \\
\hline $\mathbf{S O}{ }_{4}$ & $1.40 \mathrm{E}+03$ & $1.76 \mathrm{E}+03$ & 96.07 & $1.45 \mathrm{E}-02$ & $1.83 \mathrm{E}-02$ \\
\hline $\mathbf{T O T A L}$ & $\mathbf{1 . 0 1 E + 0 5}$ & $\mathbf{1 . 7 3 E + 0 5}$ & & $\mathbf{2 . 0 6 E + 0 0}$ & $\mathbf{3 . 3 4 E + 0 0}$ \\
\hline
\end{tabular}


Table 4 -RCRA Metals in Supernate Samples from Tanks WM-182 and WM-183 (Measurements by INEEL).

\begin{tabular}{|c|c|c|c|c|}
\hline & $\mathbf{W M - 1 8 2}$ & $\mathbf{W M - 1 8 3}$ & $\mathbf{W M - 1 8 2}$ & $\mathbf{W M - 1 8 3}$ \\
\hline & $\mathbf{m g} / \mathbf{k g}$ & $\mathbf{~ m g / k g}$ & $\mathbf{M o l e s} / \mathbf{K g}$ & Moles/Kg \\
\hline $\mathbf{S b}$ & $0.00 \mathrm{E}+00$ & $4.06 \mathrm{E}-01$ & $0.00 \mathrm{E}+00$ & $3.33 \mathrm{E}-06$ \\
\hline $\mathbf{A s}$ & $0.00 \mathrm{E}+00$ & $4.81 \mathrm{E}-01$ & $0.00 \mathrm{E}+00$ & $6.42 \mathrm{E}-06$ \\
\hline $\mathbf{B a}$ & $3.12 \mathrm{E}+00$ & $5.49 \mathrm{E}+00$ & $2.27 \mathrm{E}-05$ & $4.00 \mathrm{E}-05$ \\
\hline $\mathbf{C d}$ & $5.52 \mathrm{E}+01$ & $6.56 \mathrm{E}+01$ & $4.91 \mathrm{E}-04$ & $5.83 \mathrm{E}-04$ \\
\hline $\mathbf{C r}$ & $8.98 \mathrm{E}+01$ & $3.38 \mathrm{E}+02$ & $1.73 \mathrm{E}-03$ & $6.50 \mathrm{E}-03$ \\
\hline $\mathbf{P b}$ & $6.59 \mathrm{E}+01$ & $1.19 \mathrm{E}+02$ & $3.18 \mathrm{E}-04$ & $5.75 \mathrm{E}-04$ \\
\hline $\mathbf{H g}$ & $1.55 \mathrm{E}+02$ & $2.84 \mathrm{E}+02$ & $7.73 \mathrm{E}-04$ & $1.42 \mathrm{E}-03$ \\
\hline $\mathbf{N i}$ & $4.54 \mathrm{E}+01$ & $1.71 \mathrm{E}+02$ & $7.73 \mathrm{E}-04$ & $2.92 \mathrm{E}-03$ \\
\hline $\mathbf{S e}$ & $0.00 \mathrm{E}+00$ & $2.30 \mathrm{E}-01$ & $0.00 \mathrm{E}+00$ & $2.92 \mathrm{E}-06$ \\
\hline $\mathbf{A g}$ & $2.16 \mathrm{E}-01$ & $4.05 \mathrm{E}-01$ & $2.00 \mathrm{E}-06$ & $3.75 \mathrm{E}-06$ \\
\hline $\mathbf{Z n}$ & $2.44 \mathrm{E}+01$ & $5.99 \mathrm{E}+01$ & $3.73 \mathrm{E}-04$ & $9.17 \mathrm{E}-04$ \\
\hline $\mathbf{T o t a l}$ & & & $\mathbf{4 . 4 8 E}-03$ & $\mathbf{1 . 3 0 E}-02$ \\
\hline
\end{tabular}

The hydrogen ion concentrations for the samples are 5.3E-01 Molar for WM-182, and 2.5E+00 Molar for WM-183. The specific gravity values for the two samples are 1.1 $\mathrm{g} / \mathrm{ml}$ for WM-182 and $1.2 \mathrm{~g} / \mathrm{ml}$ for WM-183.

Insoluble Solids. The data available on the sludge samples was based on the material resulting from air-drying the sample. Air-drying the sample results in the precipitation of any soluble solids present in the interstitial supernate. Thus, the air-dried sample that was analyzed was a composite of the insoluble solids and the soluble solids. To determine the composition of the insoluble solids alone, the contribution from elements present in the soluble solids must be subtracted from the composite solids results.

The WM-183 sludge sample had a volume of $2.33 \mathrm{ml}$ and a mass of $2.91 \mathrm{~g}$ for a density of $1.25 \mathrm{~g} / \mathrm{cc}$. Allowing this sample to air-dry resulted in a loss of 1.727 grams. This loss has been attributed to water evaporation. The mass of air-dried sludge remaining was $1.179 \mathrm{~g}$. The 1.727 grams of water is equivalent to $1.727 \mathrm{ml}$ of water. It follows that $1.727 \mathrm{ml}$ of supernate were present in the $2.33 \mathrm{ml}$ sludge sample (i.e., the volume fraction of the sludge is $74 \%$ water and the mass fraction is $59.5 \%$ water). Since the density of the supernate is $1.2 \mathrm{~g} / \mathrm{ml}$, the $1.727 \mathrm{ml}$ contains $0.35 \mathrm{~g}$ of soluble solids. This implies that $0.35 \mathrm{~g} / 1.179 \mathrm{~g}$ or $30 \%$ of the total air-dried solids results from soluble solids deposited during evaporation of the sample.

No equivalent data exists for WM-182. Therefore, it was assumed that the WM-183 drying and density data were also applicable to the WM-182 sludge sample.

An element-by-element subtraction was carried out to remove the soluble solids from the total solids as measured for the air-dried sludge sample. To accomplish this, the number of moles of each species in $1.179 \mathrm{~g}$ of air-dried sludge was calculated. Then, using the actual data for the supernate samples from each tank, the moles of each species contained 
in $1.727 \mathrm{ml}$ of supernate was subtracted from the moles of each species in the air-dried sludge. The results are presented in Table 5. The final two columns present the significant chemical species, on a mole \% basis, that make up the majority of the insoluble solids.

Table 5 -Major Chemical Species in the Insoluble Solids from Tanks WM-182 and WM-183

\begin{tabular}{|c|c|c|c|c|c|c|c|c|}
\hline \multicolumn{3}{|c|}{ Total Solids } & \multicolumn{2}{|c|}{ Normalized } & \multicolumn{2}{|c|}{ Percentage } & \multirow{2}{*}{\multicolumn{2}{|c|}{\begin{tabular}{|c|c|} 
Significant & Species \\
WM-182 & WM-183
\end{tabular}}} \\
\hline Species & WM-182 & WM-183 & WM-182 & WM-183 & WM-182 & WM-183 & & \\
\hline Al & $56 \mathrm{E}-04$ & $45 \mathrm{E}-04$ & $59 E-02$ & 6.98E-02 & $6.59 \mathrm{E}+00$ & $6.98 E+00$ & $6.59 \mathrm{E}+00$ & $6.98 \mathrm{E}+00$ \\
\hline B & $9.10 \mathrm{E}-06$ & $4.31 \mathrm{E}-06$ & 1.32E-03 & $8.70 \mathrm{E}-04$ & $1.32 \mathrm{E}-01$ & 8.70E-02 & & \\
\hline $\mathrm{Ca}$ & $2.96 \mathrm{E}-05$ & $1.01 \mathrm{E}-05$ & $4.28 \mathrm{E}-03$ & $2.04 \mathrm{E}-03$ & $4.28 \mathrm{E}-01$ & $2.04 \mathrm{E}-01$ & & \\
\hline Fe & $7.56 \mathrm{E}-05$ & $3.21 \mathrm{E}-04$ & $1.09 \mathrm{E}-02$ & $6.49 \mathrm{E}-02$ & $1.09 \mathrm{E}+00$ & $6.49 \mathrm{E}+00$ & $1.09 E+00$ & $6.49 E+00$ \\
\hline $\mathrm{K}$ & $1.25 \mathrm{E}-04$ & $2.10 \mathrm{E}-04$ & 1.80E-02 & $4.23 E-02$ & $1.80 \mathrm{E}+00$ & $4.23 E+00$ & $1.80 E+00$ & $4.23 E+00$ \\
\hline $\mathrm{Mg}$ & 1.45E-05 & 7.24E-06 & $2.10 \mathrm{E}-03$ & $1.46 \mathrm{E}-03$ & 2.10E-01 & $1.46 \mathrm{E}-01$ & & \\
\hline Mn & 4.87E-06 & $1.72 \mathrm{E}-06$ & 7.04E-04 & $3.47 E-04$ & 7.04E-02 & 3.47E-02 & & \\
\hline Mo & 3.04E-05 & 7.56E-06 & 4.39E-03 & $1.53 \mathrm{E}-03$ & 4.39E-01 & $1.53 \mathrm{E}-01$ & & \\
\hline $\mathbf{N b}$ & 1.62E-05 & $7.82 \mathrm{E}-06$ & $2.34 \mathrm{E}-03$ & $1.58 \mathrm{E}-03$ & $2.34 \mathrm{E}-01$ & $1.58 \mathrm{E}-01$ & & \\
\hline Si & 1.84E-03 & 1.48E-03 & $2.66 \mathrm{E}-01$ & 2.98E-01 & $2.66 \mathrm{E}+01$ & $2.98 \mathrm{E}+01$ & $2.66 \mathrm{E}+01$ & $2.98 E+01$ \\
\hline $\mathrm{Na}$ & 8.16E-04 & $1.48 \mathrm{E}-04$ & 1.18E-01 & $2.98 \mathrm{E}-02$ & $1.18 \mathrm{E}+01$ & $2.98 \mathrm{E}+00$ & $1.18 \mathrm{E}+01$ & $2.98 E+00$ \\
\hline Sn & 4.04E-05 & $1.46 \mathrm{E}-05$ & $5.84 \mathrm{E}-03$ & $2.95 \mathrm{E}-03$ & 5.84E-01 & $2.95 \mathrm{E}-01$ & & \\
\hline$\overline{T i}$ & 1.60E-05 & 1.74E-05 & $2.31 \mathrm{E}-03$ & 3.52E-03 & $2.31 \mathrm{E}-01$ & 3.52E-01 & & \\
\hline $\mathrm{Zr}$ & 1.30E-03 & 4.49E-04 & 1.88E-01 & 9.07E-02 & $1.88 \mathrm{E}+01$ & $9.07 E+00$ & $1.88 \mathrm{E}+01$ & $9.07 E+00$ \\
\hline $\mathrm{Cl}$ & 5.28E-05 & 2.94E-05 & 7.63E-03 & 5.94E-03 & 7.63E-01 & 5.94E-01 & & \\
\hline$F$ & 8.63E-04 & 2.07E-04 & 1.25E-01 & 4.19E-02 & $1.25 \mathrm{E}+01$ & $4.19 \mathrm{E}+00$ & $1.25 \mathrm{E}+01$ & 4.19E+00 \\
\hline $\mathrm{NO}_{3}$ & $0.00 \mathrm{E}+00$ & $0.00 \mathrm{E}+00$ & $0.00 \mathrm{E}+00$ & $0.00 \mathrm{E}+00$ & $0.00 \mathrm{E}+00$ & $0.00 \mathrm{E}+00$ & & \\
\hline $\mathrm{PO}_{4}$ & 8.49E-04 & $1.56 \mathrm{E}-03$ & $1.23 \mathrm{E}-01$ & $3.16 \mathrm{E}-01$ & $1.23 \mathrm{E}+01$ & $3.16 \mathrm{E}+01$ & $1.23 E+01$ & $3.16 \mathrm{E}+01$ \\
\hline $\mathrm{SO}_{4}$ & 3.80E-04 & $1.29 \mathrm{E}-04$ & 5.49E-02 & $2.60 \mathrm{E}-02$ & $5.49 \mathrm{E}+00$ & $2.60 \mathrm{E}+00$ & $5.49 \mathrm{E}+00$ & $2.60 \mathrm{E}+00$ \\
\hline TOTAL & 6.92E-03 & 4.95E-03 & $1.00 \mathrm{E}+00$ & $1.00 \mathrm{E}+00$ & $1.00 \mathrm{E}+02$ & $1.00 \mathrm{E}+02$ & $9.69 \mathrm{E}+01$ & $9.80 \mathrm{E}+01$ \\
\hline
\end{tabular}

Thus, the major species present in the insoluble solids, on a mole $\%$ basis, are summarized below.

\begin{tabular}{|c|c|c|}
\hline WM-182 & & WM-183 \\
\hline 6.6 & Al & 7 \\
\hline 1.1 & Fe & 6.5 \\
\hline 1.8 & $\mathrm{~K}$ & 4.2 \\
\hline 26.6 & $\mathrm{Si}$ & 29.8 \\
\hline 11.8 & $\mathrm{Na}$ & 3 \\
\hline 18.8 & $\mathrm{Zr}$ & 9.1 \\
\hline 12.5 & $\mathrm{~F}$ & 4.2 \\
\hline 12.3 & $\mathrm{PO4}$ & 31.6 \\
\hline 5.5 & $\mathrm{SO}$ & 2.6 \\
\hline 0.0 & $\mathrm{NO3}$ & 0.0 \\
\hline
\end{tabular}


A separate calculation was performed with the intent of exactly eliminating all nitrate from the sludge sample by subtraction of an amount of supernate that accomplished this goal. The results (again on a mole \% basis), which are not markedly different than the first calculation are:

\begin{tabular}{|c|c|c|}
\hline WM-182 & Species & WM-183 \\
\hline 8.9 & Al & 10.3 \\
\hline 1.1 & Fe & 6.1 \\
\hline 2.2 & $\mathrm{~K}$ & 4.4 \\
\hline 24.3 & $\mathrm{Si}$ & 26.4 \\
\hline 15.1 & $\mathrm{Na}$ & 7.9 \\
\hline 17.2 & $\mathrm{Zr}$ & 8.0 \\
\hline 11.7 & $\mathrm{~F}$ & 4.1 \\
\hline 11.2 & $\mathrm{PO4}$ & 27.9 \\
\hline 5.2 & $\mathrm{SO}$ & 2.5 \\
\hline 0.0 & NO3 & 0.0 \\
\hline
\end{tabular}

Finally, the results (mole \%) for no subtraction of the supernate from the sludge composition can be compared to the above two results. An expected difference is the large amount of nitrate and sodium present in these compositions:

\begin{tabular}{|c|c|c|}
\hline WM-182 & Species & WM-183 \\
\hline 9.8 & Al & 10.5 \\
\hline 1 & Fe & 3.7 \\
\hline 2.2 & $\mathrm{~K}$ & 3.1 \\
\hline 18.9 & $\mathrm{Si}$ & 14.3 \\
\hline 16 & $\mathrm{Na}$ & 10.6 \\
\hline 13.4 & $\mathrm{Zr}$ & 4.4 \\
\hline 9.4 & $\mathrm{~F}$ & 2.6 \\
\hline 8.7 & $\mathrm{PO}$ & 15.1 \\
\hline 4.2 & $\mathrm{SO}$ & 1.6 \\
\hline 13.8 & NO3 & 32.1 \\
\hline
\end{tabular}

These results demonstrate that the solids (with supernate contribution subtracted) of Tank WM-182 have higher levels of $\mathrm{Zr}, \mathrm{F}, \mathrm{Na}$, and $\mathrm{SO}_{4}$ than the solids of Tank WM-183. On the other hand, the solids of Tank WM-183 contain higher levels of Fe, $\mathrm{K}$, and $\mathrm{PO}_{4}$ than the solids from WM-183. However, the solids from both tanks contain the same major chemical components.

RCRA Metals. The data for the RCRA metals are provided in Table 6. These data were obtained by subtracting out the contribution of RCRA metals from the supernate in an equivalent fashion to the results produced for the major chemical species (see discussion preceding Table 5). 
Table 6-RCRA Metals in the Insoluble Solids from Tanks WM-182 and WM-183

\begin{tabular}{|c|c|c|c|c|c|c|c|c|}
\hline \multicolumn{2}{|c|}{ Total Solids } & \multicolumn{2}{c|}{ Normalized } & \multicolumn{2}{c|}{ Percentage } & Significant & Species \\
\hline Species & WM-182 & WM-183 & WM-182 & WM-183 & WM-182 & WM-183 & WM-182 & WM-183 \\
\hline Sb & $1.36 \mathrm{E}-07$ & $3.03 \mathrm{E}-07$ & $4.76 \mathrm{E}-03$ & $2.07 \mathrm{E}-02$ & $4.76 \mathrm{E}-01$ & $2.07 \mathrm{E}+00$ & & $\mathbf{2 . 0 7 E + 0 0}$ \\
\hline $\mathbf{A s}$ & $4.42 \mathrm{E}-06$ & $8.68 \mathrm{E}-07$ & $1.55 \mathrm{E}-01$ & $5.93 \mathrm{E}-02$ & $1.55 \mathrm{E}+01$ & $5.93 \mathrm{E}+00$ & $\mathbf{1 . 5 5 E + 0 1}$ & $\mathbf{5 . 9 3 E + 0 0}$ \\
\hline $\mathbf{B a}$ & $1.05 \mathrm{E}-06$ & $1.23 \mathrm{E}-07$ & $3.68 \mathrm{E}-02$ & $8.41 \mathrm{E}-03$ & $3.68 \mathrm{E}+00$ & $8.41 \mathrm{E}-01$ & $\mathbf{3 . 6 8 E + 0 0}$ & \\
\hline $\mathbf{C d}$ & $2.48 \mathrm{E}-06$ & $2.80 \mathrm{E}-07$ & $8.69 \mathrm{E}-02$ & $1.92 \mathrm{E}-02$ & $8.69 \mathrm{E}+00$ & $1.92 \mathrm{E}+00$ & $\mathbf{8 . 6 9 E}+\mathbf{0 0}$ & $\mathbf{1 . 9 2 E + 0 0}$ \\
\hline $\mathbf{C r}$ & $9.24 \mathrm{E}-06$ & $8.05 \mathrm{E}-06$ & $3.24 \mathrm{E}-01$ & $5.50 \mathrm{E}-01$ & $3.24 \mathrm{E}+01$ & $5.50 \mathrm{E}+01$ & $\mathbf{3 . 2 4 E + 0 1}$ & $\mathbf{5 . 5 0 E + 0 1}$ \\
\hline $\mathbf{P b}$ & $1.50 \mathrm{E}-06$ & $3.67 \mathrm{E}-07$ & $5.25 \mathrm{E}-02$ & $2.51 \mathrm{E}-02$ & $5.25 \mathrm{E}+00$ & $2.51 \mathrm{E}+00$ & $\mathbf{5 . 2 5 E + 0 0}$ & $\mathbf{2 . 5 1 E + 0 0}$ \\
\hline $\mathbf{H g}$ & $3.54 \mathrm{E}-07$ & $-1.03 \mathrm{E}-06$ & $1.24 \mathrm{E}-02$ & $-7.04 \mathrm{E}-02$ & $1.24 \mathrm{E}+00$ & & $\mathbf{1 . 2 4 E + 0 0}$ & $\mathbf{- 7 . 0 4 E + 0 0}$ \\
\hline $\mathbf{N i}$ & $4.74 \mathrm{E}-06$ & $2.33 \mathrm{E}-06$ & $1.66 \mathrm{E}-01$ & $1.59 \mathrm{E}-01$ & $1.66 \mathrm{E}+01$ & $1.59 \mathrm{E}+01$ & $\mathbf{1 . 6 6 E + 0 1}$ & $\mathbf{1 . 5 9 E + 0 1}$ \\
\hline $\mathbf{S e}$ & $1.36 \mathrm{E}-06$ & $1.88 \mathrm{E}-07$ & $4.77 \mathrm{E}-02$ & $1.28 \mathrm{E}-02$ & $4.77 \mathrm{E}+00$ & $1.28 \mathrm{E}+00$ & $\mathbf{4 . 7 7 E}+\mathbf{0 0}$ & $\mathbf{1 . 2 8 E + 0 0}$ \\
\hline $\mathbf{A g}$ & $7.07 \mathrm{E}-07$ & $2.40 \mathrm{E}-06$ & $2.48 \mathrm{E}-02$ & $1.64 \mathrm{E}-01$ & $2.48 \mathrm{E}+00$ & $1.64 \mathrm{E}+01$ & $\mathbf{2 . 4 8 E + 0 0}$ & $\mathbf{1 . 6 4 E + 0 1}$ \\
\hline $\mathbf{Z n}$ & $2.52 \mathrm{E}-06$ & $7.69 \mathrm{E}-07$ & $8.84 \mathrm{E}-02$ & $5.25 \mathrm{E}-02$ & $8.84 \mathrm{E}+00$ & $5.25 \mathrm{E}+00$ & $\mathbf{8 . 8 4 E + 0 0}$ & $\mathbf{5 . 2 5 E + 0 0}$ \\
\hline Total & $2.85 \mathrm{E}-05$ & $1.46 \mathrm{E}-05$ & $1.00 \mathrm{E}+00$ & $1.00 \mathrm{E}+00$ & $1.00 \mathrm{E}+02$ & $1.00 \mathrm{E}+02$ & $\mathbf{9 . 9 5 E + 0 1}$ & $\mathbf{9 . 9 2 E + 0 1}$ \\
\hline
\end{tabular}

The distribution of RCRA metals between insoluble solids and soluble solids can be divided into three groups for WM-183. The first group contains only $\mathrm{Hg}$, which appears to come completely from the soluble solids. The second group of $\mathrm{Cd}, \mathrm{Cr}, \mathrm{Pb}, \mathrm{Ni}$, and $\mathrm{Zn}$ had significant contributions to the total solids RCRA metals from both soluble and insoluble solids. Finally, the third group contains those elements that come essentially from the insoluble solids. These include $\mathrm{Ag}, \mathrm{As}, \mathrm{Ba}, \mathrm{Se}$, and $\mathrm{Sb}$.

There were significant differences in the amounts of RCRA metals present in the insoluble solids from both WM-182 and WM-183. Tank WM-182 insoluble solids had higher levels of As, Cd, Hg, and Zn than the solids in WM-183. Conversely, Tank WM183 insoluble solids had higher levels of $\mathrm{Cr}$ and $\mathrm{Ag}$ than the solids from Tank WM-182.

For WM-183, the major RCRA metals in the insoluble solids were $\mathrm{Cr}, \mathrm{Ni}$, and $\mathrm{Ag}$ and for Tank WM-182, the major RCRA metals in the insoluble solids were As, Cr, Ni, and Zn.

\section{Evaluation and Analysis of the Reported Radionuclide Compositions for WM-182 and WM-183 Solids}

The concentrations of the major radionuclides present in the sludge sample (total solids) and in the supernate for both WM-182 and WM-183 are provided in Table 7. Although the overall radionuclide levels are approximately the same in the supernate fractions of both WM-182 and WM-183, the solid sludge sample from WM-182 has a significantly higher (4.5 times) overall Curie content than WM-183. 
Table 7 -Composition of Major Radionuclides for Air-Dried Solid Samples and from Supernate Samples of Tanks WM-182 and WM-183 (Measurements by INEEL).

\begin{tabular}{|c|c|c|c|c|}
\hline & Sludge & Sludge & Supernate & Supernate \\
\hline & WM-182 & WM-183 & WM-182 & WM-183 \\
\hline & $\mathrm{mCi} / \mathrm{g}$ & $\mathrm{mCi} / \mathrm{g}$ & $\mathrm{mCi} / \mathrm{L}$ & $\mathrm{mCi} / \mathrm{L}$ \\
\hline Co-60 & $2.14 \mathrm{E}-04$ & $0.00 \mathrm{E}+00$ & 1.90E-01 & 6.00E-01 \\
\hline Sr-90 & $2.29 \mathrm{E}-01$ & 1.82E-01 & $1.50 \mathrm{E}+02$ & $1.60 \mathrm{E}+02$ \\
\hline Tc-99 & 2.63E-03 & 3.29E-05 & 2.20E-02 & 4.20E-02 \\
\hline Sb-125 & 5.77E-02 & $2.90 \mathrm{E}-03$ & 5.00E-02 & $9.10 \mathrm{E}-02$ \\
\hline Cs-134 & 6.64E-03 & 5.89E-04 & $2.90 \mathrm{E}-01$ & 1.70E-01 \\
\hline Cs-137 & $4.50 \mathrm{E}+00$ & 8.68E-01 & $1.50 \mathrm{E}+02$ & $1.60 \mathrm{E}+02$ \\
\hline Eu-154 & 1.48E-03 & 7.56E-04 & 4.20E-01 & 5.40E-01 \\
\hline Eu-155 & $0.00 \mathrm{E}+00$ & $0.00 \mathrm{E}+00$ & 1.10E-01 & 1.60E-01 \\
\hline U-235 & $2.61 \mathrm{E}-07$ & 9.29E-08 & 7.30E-06 & 1.40E-05 \\
\hline U-238 & 3.83E-08 & $6.91 \mathrm{E}-08$ & 1.10E-05 & 2.00E-05 \\
\hline Pu-238 & 1.93E-02 & 4.00E-03 & $1.10 \mathrm{E}+00$ & $1.10 \mathrm{E}+00$ \\
\hline Pu-239 & 1.47E-03 & 1.25E-03 & $1.50 \mathrm{E}-01$ & 1.60E-01 \\
\hline Am-241 & 8.46E-04 & 2.45E-04 & 1.30E-01 & 1.40E-01 \\
\hline Total & $4.82 \mathrm{E}+00$ & $1.06 \mathrm{E}+00$ & $3.02 E+02$ & $3.23 \mathrm{E}+02$ \\
\hline
\end{tabular}

Following the same process (see Tables 5 and 6) in which the supernate contribution of radionuclides is subtracted from the overall sludge radionuclides gives the radionuclide concentrations present in the insoluble solids only. These data are provided in Table 8.

\section{Table 8 - Major Radionuclide Concentrations for the Insoluble Solids from Tanks WM-182 and WM-183}

\begin{tabular}{|c|c|c|}
\hline & WM-182 & WM-183 \\
\hline & $\mathbf{m C i} / \mathbf{1 . 1 7 9} \mathbf{~ g}$ & $\mathbf{m C i} / \mathbf{1 . 1 7 9} \mathbf{~ g}$ \\
\hline Co-60 & $-7.58 \mathrm{E}-05$ & Not reported \\
\hline Sr-90 & $1.09 \mathrm{E}-02$ & $-6.17 \mathrm{E}-02$ \\
\hline Tc-99 & $3.06 \mathrm{E}-03$ & $-3.37 \mathrm{E}-05$ \\
\hline Sb-125 & $6.79 \mathrm{E}-02$ & $3.26 \mathrm{E}-03$ \\
\hline Cs-134 & $7.33 \mathrm{E}-03$ & $4.01 \mathrm{E}-04$ \\
\hline Cs-137 & $5.05 \mathrm{E}+00$ & $7.47 \mathrm{E}-01$ \\
\hline Eu-154 & $1.02 \mathrm{E}-03$ & $-4.13 \mathrm{E}-05$ \\
\hline Eu-155 & $-1.90 \mathrm{E}-04$ & $-2.76 \mathrm{E}-04$ \\
\hline $\mathbf{U}-235$ & $2.95 \mathrm{E}-07$ & $8.54 \mathrm{E}-08$ \\
\hline $\mathbf{U}-238$ & $2.62 \mathrm{E}-08$ & $4.69 \mathrm{E}-08$ \\
\hline Pu-238 & $2.09 \mathrm{E}-02$ & $2.82 \mathrm{E}-03$ \\
\hline Pu-239 & $1.47 \mathrm{E}-03$ & $1.20 \mathrm{E}-03$ \\
\hline Am-241 & $7.73 \mathrm{E}-04$ & $4.71 \mathrm{E}-05$ \\
\hline Total & $5.16 \mathrm{E}+00$ & $6.92 \mathrm{E}-01$ \\
\hline
\end{tabular}


For the solids from Tank WM-183, the radionuclide contribution to the total solids can be separated into two groups. The first group contains those radionuclides that arise mainly from the supernate. These include Sr-90, Tc-99, Eu-154, and Am-241. The second group contains those radionuclides in the total solids that arise mainly from the insoluble solids: Sb-125, Cs-134, Cs-137, U-235, Pu-238, and Pu-239. The distribution for the solids from Tank WM-182 are (1) supernate: Co-60 and Sr-90 and (2) insoluble solids: Tc-99, Sb-125, Cs-134, Cs-137, Cu-154, U-235, Pu-238, Pu-239, and Am-241.

The majority of the radioactivity in the insoluble solids comes from Cs-137. The majority of the TRU component from the insoluble solids comes from $\mathrm{Pu}-238$. These calculations also show that approximately half of the radioactivity from Tank WM-183 total solids is associated with the soluble radionuclides from the supernate. On the other hand, only $10 \%$ of radioactivity from WM-182 total solids is associated with soluble radionuclides from the supernate.

\section{Prediction of Solid Phases by OLI Modeling}

An initial effort was performed using OLI modeling to predict the solid phases that may form in Tank WM-183. Input for the model included the data available on the supernate composition for WM-183 and the available data for total solids from Tank WM-183. Adjustments were made to the input to ensure charge balance as described in Attachment 1 to this report.

The model predicted the presence of several solids including silica, zirconia, and iron phosphate. The model also revealed the problem with excess phosphate $\left(\mathrm{P}_{2} \mathrm{O}_{5}\right.$ is not a stable species in acid media) and lack of charge balance.

Complete details of this initial effort are presented in Attachment 1.

\section{Waste Form Production and Disposition For Each Option}

The following are the major waste forms generated for each option (5) and the expected disposal site for each waste form (assuming a favorable WIR ruling).

1. Calcining. The blend of solid and liquid will produce a composite calcine that will be RH TRU waste that can be sent to WIPP. Estimated number of canisters is 1375 .

2. Steam Reforming. The blend of solid and liquid will produce a composite ceramic waste form that will be RH TRU waste that can be sent to WIPP. Estimated number of canisters is 831 .

3. Cesium Ion Exchange and Grouting. The solids separated from the waste will be dried resulting in $150 \mathrm{~m}^{3}$ of RH TRU. The effluent (reduced in Cs-137) will be grouted to produce $\sim 4,150 \mathrm{~m}^{3}$ of $\mathrm{CH}$ TRU waste. An alternative to grouting is to dry the solution using silica gel to produce a waste form that, depending on the amount of silica used, will be either $\mathrm{CH}$ or RH TRU waste. This alternative has been identified in case the waste in the tanks is later shown not to be WIR. In this 
case it will have to be vitrified and recovery from a silica based waste form is easier than from the grouted form. There will also be $20 \mathrm{~m}^{3}$ of cesium loaded CST, which may or may not be TRU waste.

4. Direct Evaporation. This process will dry separately the solids and liquids. The liquids will have silica gel added to it. The drying will produce a total of 909 canisters from the liquid SBW and 133 canisters from the solids that are RH TRU destined for WIPP. In addition, there will be between 1200 and $3550 \mathrm{~m}^{3}$ of $\mathrm{CH}$ LAW grouted waste produced depending on the formulation.

\section{$\underline{\text { Simulant Requirements }}$}

The simulant requirements are driven by the properties of the waste that can impact processing performance, waste form performance and off-gas regulatory compliance.

Processing. The waste properties of interest to processing include yield stress and viscosity (rheological properties), settling time of the solids, ease of re-suspension, solids loading, and flocculation or aggregation of the particles as the $\mathrm{pH}$ and supernate concentrations change.

Waste Form. The waste properties of interest to waste form performance are somewhat limited for those waste forms that will be shipped to WIPP. Idaho has taken an approach that will preclude the requirement of LDR compliance. This is consistent with the WIPP WAC that does not require LDR compliance. Thus, the waste forms, whether produced from calcining, steam reforming, drying etc will have no requirements on leaching performance. However, the waste forms must not contain or develop standing free liquids. Furthermore, the dose rates need to be controlled to avoid the highest level of RH waste accepted at WIPP (100 to $1000 \mathrm{Rem} / \mathrm{hr}$ ).

Off-Gas. Those elements controlled by the permit in the off-gas stream are of interest for inclusion in the simulant. Generally, these are at relatively low levels in the waste and can be added as required to the simulant to ensure compliance with off-gas regulations.

\section{$\underline{\text { Issues Relative to Simulant Development }}$}

There are a number of issues that emerged during this task relative to solid simulant development.

Limited Data. The physical properties of the sludge upon air-drying are available only for WM-183. These data included weight loss upon drying and density of slurry (volume and mass of the sludge sample before drying). Therefore, an assumption had to be made for WM-182 that the weight loss and density were equivalent. The lack of XRD and SEM data on the solids precludes direct identification/confirmation of mineral phases that form in this tank environment. 
Impact of Additional Processing. There is a requirement that the solids transferred to the processor will be a mixture of several tanks. The only data available now demonstrates that there are significant differences between the solids in WM-182 and WM-183. Therefore, the actual solids processed will be a composite with a variance in composition that is currently unknown. The process of removal of the solids from a tank and transfer to WM-187 and eventually to the processing hold tank results in significant dilution of the solids. The next step in the process, which is settling of the solids and decanting of the supernate, removes much of the soluble salts from the interstitial liquid of the sludge. If this data is deemed important to validation (see Section of Simulant Validation), then it will be necessary to measure the effect of dilution and removal of soluble solids on the physical and chemical nature of the insoluble solids.

Lack of Charge Balance. The data for WM-183 solids indicates a great deal of phosphate in the solids. To charge balance this phosphate, along with the other anions, requires significantly higher concentrations of cations than were detected. This apparent disconnect needs resolution through further analysis (SEM and XRD) and modeling. The initial OLI modeling effort also indicates a lack of charge balance in the supernate composition (See Appendix 1).

\section{Initial Simulant Development}

Although the issues identified above limit the development of a representative simulant, the process of simulant development was begun with the fabrication of an initial simulant. This initial simulant will provide a baseline simulant to which modifications can be made, pending new data and dependent on the simulant requirements that will be identified for testing.

To match the physical properties of this initial simulant, a slurry was formulated to provide a particle size distribution that roughly corresponded to that measured for the sludge samples from WM-182 and WM-183. This included the incorporation of micronsized particles as well as silica particles in the range of 20 to 40 microns. Solids settling, redispersion and rheological properties have not yet been measured for the actual waste and these properties will ultimately depend on the extent of washing during preprocessing.

For chemical simulation, the water content of the slurry, ( $\sim 60 \%$ by weight) was adjusted to roughly match the water content of WM-183. In this initial effort, chemical simulation was achieved for most elements and anions. However, sodium and potassium were replaced by calcium in the form of calcium fluoride and calcium sulfate (insoluble salts). To accommodate the large amount of phosphate in the solids, Tri-Basic calcium phosphate was added. This introduces more calcium than was detected in the sludge slurry.

Table 9 presents the batching sheet of chemicals prescribed to make the initial simulant while Table 10 provides the comparison between the chemical compositions (on a mole $\mathrm{wt} \%$ ) of the actual waste to the simulant (on a mole wt \%). 
Table 9 - Batch Sheet for Solid Simulant from WM-183 (28.14 grams of Water were Added to this Solid Mixture)

\begin{tabular}{|c|c|}
\hline Chemical Compound & Grams Added \\
\hline $\mathrm{Fe}_{2} \mathrm{O}_{3}$ & 1.04 \\
\hline $\mathrm{CaF}_{2}$ & 0.33 \\
\hline $\mathrm{Ca}_{10}(\mathrm{OH})_{2}\left(\mathrm{PO}_{4}\right)_{6}$ & 10.58 \\
\hline $\mathrm{Al}_{4} \mathrm{Si}_{4} \mathrm{O}_{10}(\mathrm{OH})_{8}$ & 1.52 \\
\hline $\mathrm{CaSO}_{4}{ }^{*} 1 / 2 \mathrm{H}_{2} \mathrm{O}$ & 0.75 \\
\hline $\mathrm{ZrSiO}_{4}$ & 3.34 \\
\hline $\mathrm{SiO}_{2}$ & 1.64 \\
\hline TOTAL & 19.21 \\
\hline
\end{tabular}

Table 10 - Comparison Between the Chemical Compositions of the Actual Waste and the Simulant

\begin{tabular}{|c|c|c|}
\hline Species & Mole $\%$ & Mole \% \\
\hline & Actual Waste & Simulant \\
\hline $\mathrm{Al}$ & 7 & 7 \\
\hline $\mathrm{Fe}$ & 6.5 & 6.5 \\
\hline $\mathrm{K}$ & 4.2 & 0 \\
\hline $\mathrm{Si}$ & 29.8 & 29.8 \\
\hline $\mathrm{Na}$ & 3 & 0 \\
\hline $\mathrm{Zr}$ & 9.1 & 9.1 \\
\hline $\mathrm{F}$ & 4.2 & 4.2 \\
\hline $\mathrm{PO}_{4}$ & 31.6 & 31.6 \\
\hline $\mathrm{SO}_{4}$ & 2.6 & 2.6 \\
\hline
\end{tabular}

As discussed above, the $\mathrm{K}$ and $\mathrm{Na}$ are at $0 \%$ in the simulant due to the addition of insoluble calcium salts. Further $\mathrm{Ca}$ was added in the form of calcium phosphate and consequently the simulant has much more calcium than is present in the actual waste.

An additional simulant was prepared using $0.4 \mathrm{~N} \mathrm{HNO}_{3}$ as the liquid additive. This concentration value for nitric acid was chosen to mimic the final acid concentration of the slurry after 'washing'. The actual solids content of the slurry will be variable during operations. As discussed above, transfer of the slurry from tank to tank will require dilution. For the calcining and steam reforming options, the solids will be blended to form slurry feed to the processors. An estimate will have to be made for the range of solids loading that will be anticipated during operations for each of the options in order to finalize simulant requirements. 
Both of simulants produced were orange/red in color and tended to coat and adhere to the glass vessel in which they were stored. Settling did occur with a small clear layer of supernate on top of the slurry. This is similar to the settling behavior observed with actual waste from WM-182. Re-dispersion could be readily achieved by shaking, but the solids would resettle over time resulting in a small clear supernate layer on top of the slurry.

The particle size distribution (on a volume basis) of the simulant prepared using the recipe from Table 9 is provided in Figure 1. 


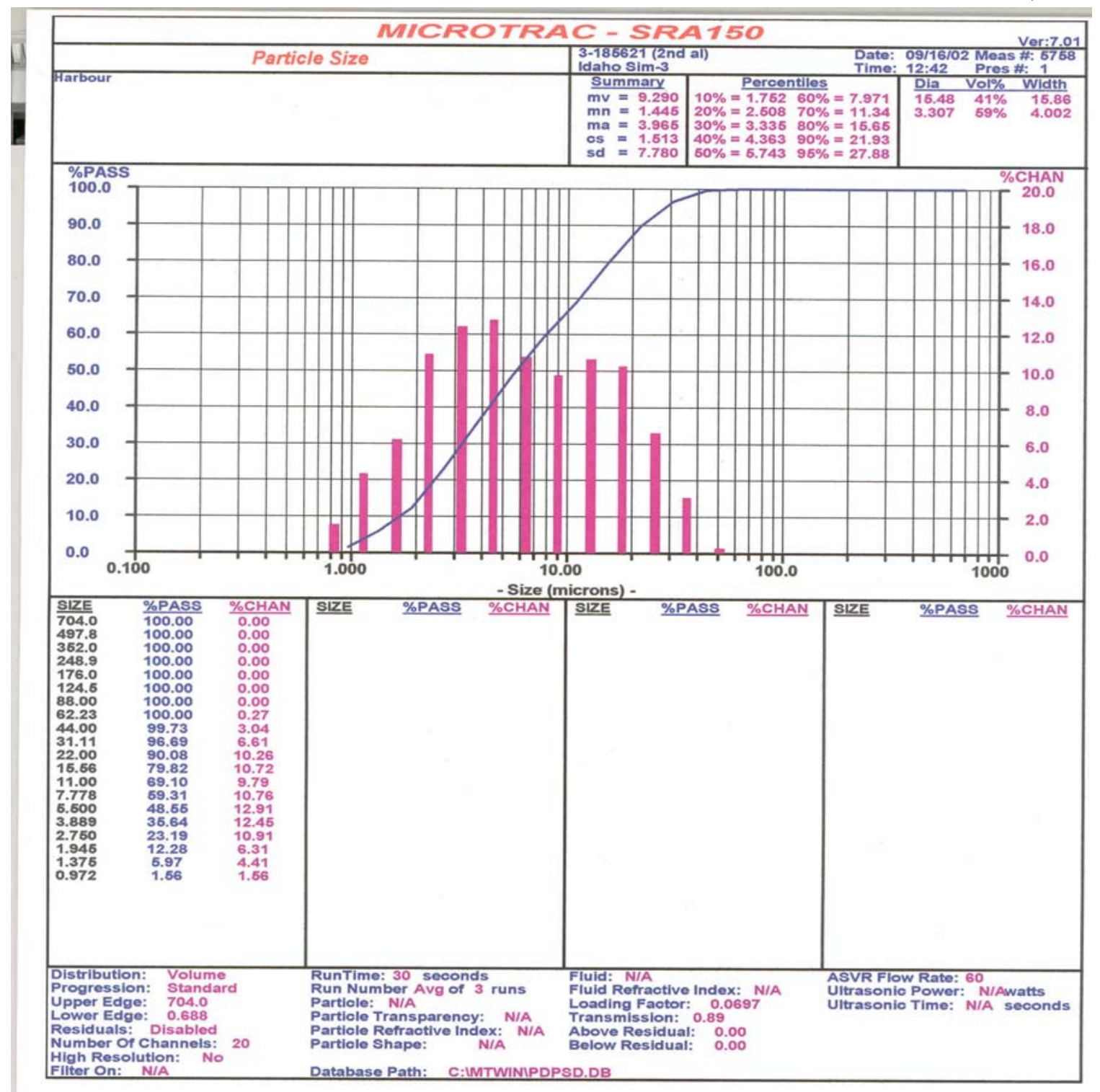

Figure 1. Particle Size Distribution for Simulant Defined in Table 9.

A Haake RS150 rheometer was used to measure the rheological properties of the two samples. Sample 1 was the simulant prepared to the recipe shown in Table 9 and Sample 2 was the simulant that was prepared using $0.4 \mathrm{~N} \mathrm{HNO}_{3}$. Due to the sample sizes provided, a plate to plate geometry was used to obtain the rheological properties. The top disk was $60 \mathrm{~mm}$ in diameter and was located 500 microns above the bottom plate. The sample was placed on the bottom plate and as the top disk was driven to the 500 micron position, any excess sample that squeezed out between the plates was removed so as to 
minimize end effects. All flow properties were measured at $25^{\circ} \mathrm{C}$. All flow curves were measured with increasing shear rate from 0 to $2000 \mathrm{sec}^{-1}$ in 5 minutes, holding shear rate $2000 \mathrm{sec}^{-1}$ for $30 \mathrm{~seconds}$, and then reducing the shear rate from $2000 \mathrm{to} \mathrm{sec}^{-1}$ in 5 minutes. The flow curves have not been corrected for non-Newtonian behavior.

The flow curves were fitted with the following rheological models:

Bingham Plastic: $\tau=\tau_{B}+\eta \cdot j$

Power Law: $\tau=k \cdot \dot{\gamma}^{n}$

Herschel-Bulkley: $\tau=\tau_{H B}+k_{H B} \cdot \dot{\gamma}^{n_{H B}}$

Where:

$$
\begin{aligned}
& \tau=\text { shear stress }(\mathrm{Pa}) \\
& j=\text { shear rate }\left(\mathrm{sec}^{-1}\right) \\
& \tau_{\mathrm{B}}=\text { Bingham Plastic Yield Stress }(\mathrm{Pa}) \\
& \eta=\text { consistency or infinite viscosity }(\mathrm{Pa}-\mathrm{sec}) \\
& \mathrm{k}=\text { power law consistency }\left(\mathrm{Pa}-\mathrm{sec}^{\mathrm{n}}\right) \\
& \mathrm{n}=\text { power law index } \\
& \tau_{\mathrm{HB}}=\text { Herschel-Bulkley Yield Stress }(\mathrm{Pa}) \\
& \mathrm{k}_{\mathrm{HB}}=\text { Herschel-Bulkley consistency }\left(\mathrm{Pa}-\mathrm{Sec}^{\mathrm{n}}\right) \\
& \mathrm{n}_{\mathrm{HB}}=\text { Herschel-Bulkley flow behavior index }
\end{aligned}
$$

Figures 2 and 3 provide the results of the rheological measurement. The data for both simulants showed thixotropic characteristics. Neither of the samples appeared to have a defined yield stress. 


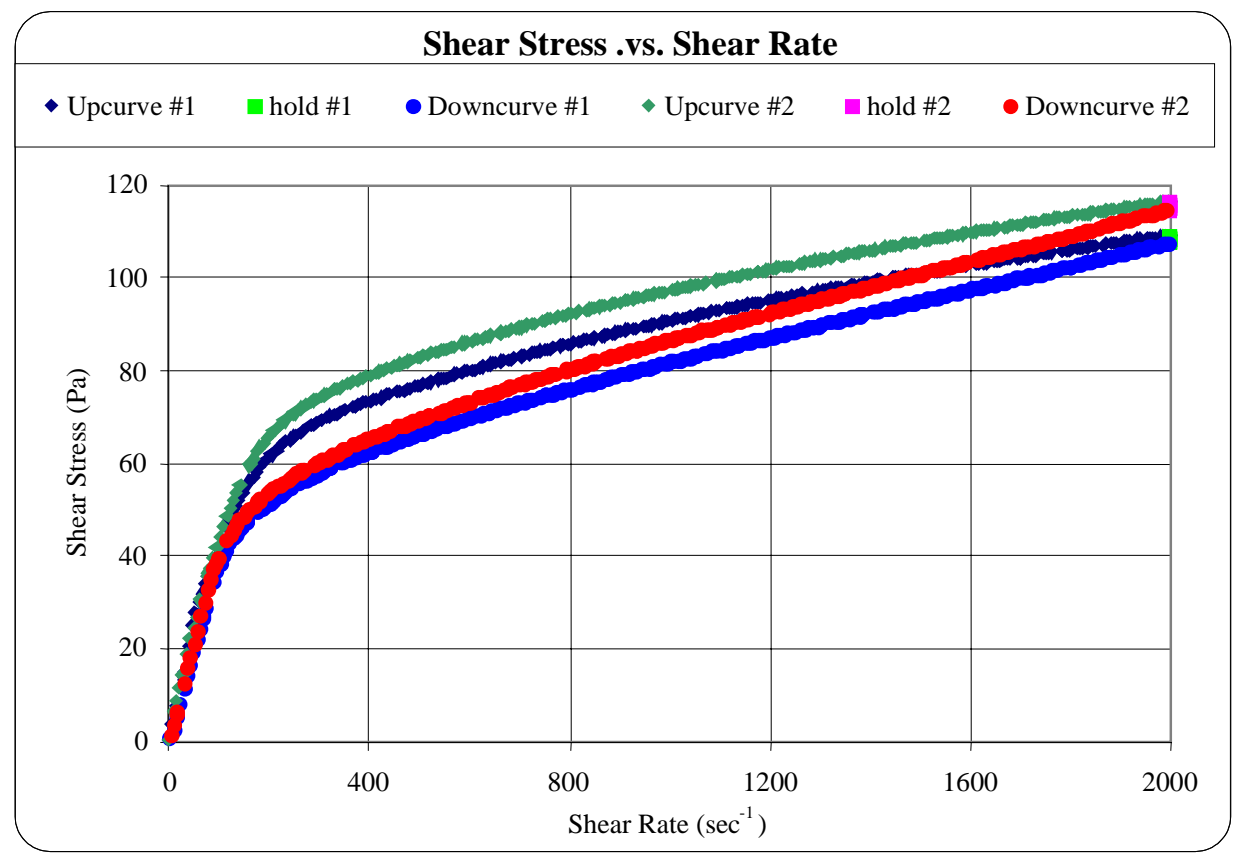

Figure 2. Shear Stress versus Shear Rate; Sample 1 Results

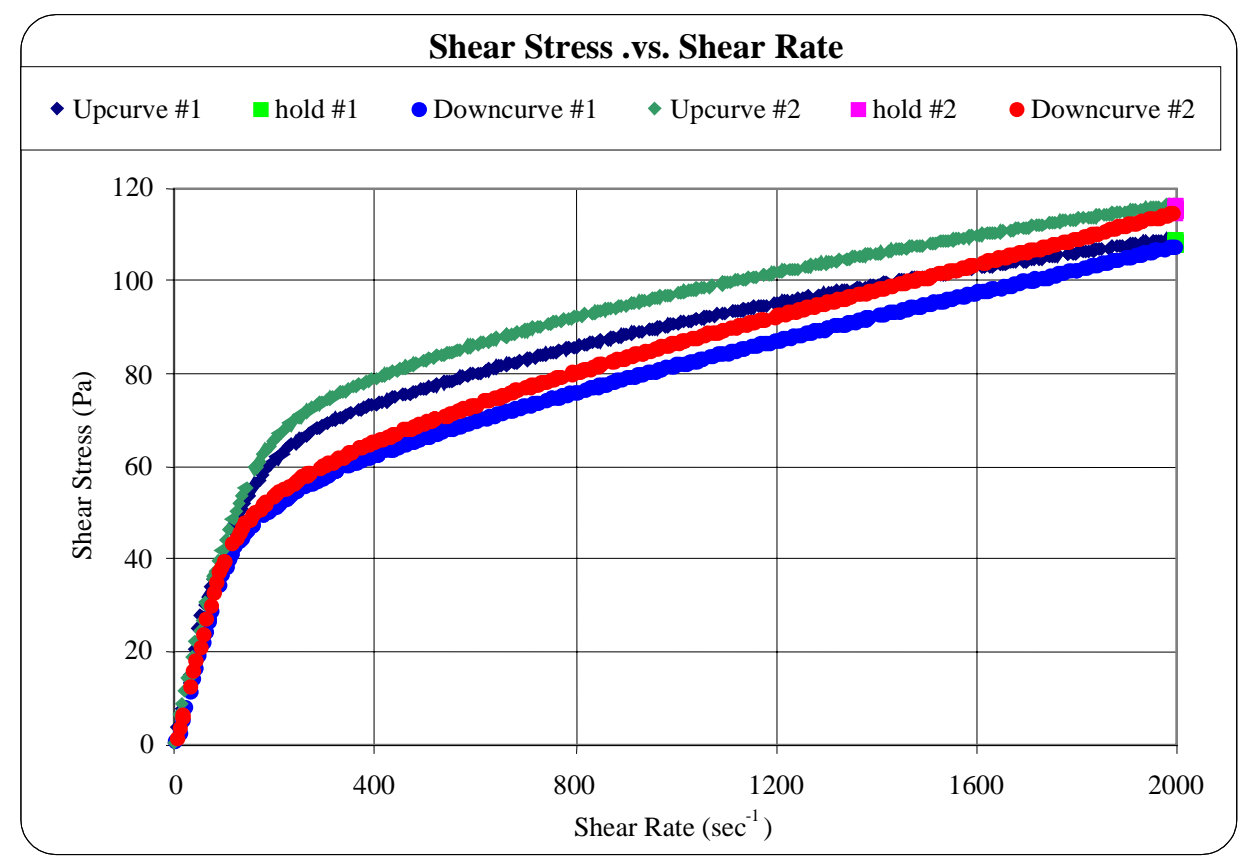

Figure 3. Shear Stress versus Shear Rate; Sample 2 Results 
The up and down flow curves results for each of the runs are provided in Tables 11, 12, and 13 for each rheological model.

Table 11. Bingham Plastic Parameters

\begin{tabular}{|c|c|c|c|c|c|}
\hline & & & Yield Stress & Consistency & \\
\hline Sample & Curve & run & $\mathbf{P a}$ & Pa-sec & $\mathbf{R}^{\mathbf{2}}$ \\
\hline 1 & Up & 1 & 67.78 & 0.0218 & 0.9853 \\
\hline & & 2 & 73.35 & 0.0227 & 0.9937 \\
\hline 1 & Down & 1 & 53.88 & 0.0273 & 0.9987 \\
\hline & & 2 & 56.00 & 0.0299 & 0.9986 \\
\hline 2 & Up & 1 & 43.87 & 0.0194 & 0.9883 \\
\hline & & 2 & 43.22 & 0.0191 & 0.9905 \\
\hline 2 & Down & 1 & 30.63 & 0.0241 & 0.9990 \\
\hline & & 2 & 31.12 & 0.0234 & 0.9991 \\
\hline
\end{tabular}

Table 12. Power Law Parameters

\begin{tabular}{|c|c|c|c|c|c|}
\hline & & & Consistency & Index (n) & \\
\hline Sample & Curve & run & $\mathbf{P a}-\mathbf{s e c}^{\mathbf{n}}$ & Unitless & $\mathbf{R}^{2}$ \\
\hline 1 & Up & 1 & 12.75 & 0.284 & 0.9853 \\
\hline & & 2 & 13.75 & 0.283 & 0.9833 \\
\hline 1 & Down & 1 & 7.64 & 0.346 & 0.9927 \\
\hline & & 2 & 7.65 & 0.354 & 0.9941 \\
\hline 2 & Up & 1 & 6.68 & 0.328 & 0.9958 \\
\hline & & 2 & 6.52 & 0.329 & 0.9959 \\
\hline 2 & Down & 1 & 3.13 & 0.419 & 0.9964 \\
\hline & & 2 & 3.34 & 0.409 & 0.9962 \\
\hline
\end{tabular}

Table 13. Herschel-Bulkley Parameters

\begin{tabular}{|c|c|c|c|c|c|c|}
\hline & & & Yield Stress & Consistency $^{\text {Index (n) }}$ & \\
\hline Sample & Curve & Run & $\mathbf{P a}$ & $\mathbf{P a}-\mathbf{s e c}^{\mathbf{n}}$ & Unitless & $\mathbf{R}^{\mathbf{2}}$ \\
\hline 1 & Up & 1 & -33.43 & 31.95 & 0.197 & 0.9899 \\
\hline & & 2 & -39.98 & 37.11 & 0.19 & 0.9886 \\
\hline 1 & Down & 1 & -25.90 & 19.73 & 0.248 & 0.9948 \\
\hline & & 2 & -22.77 & 17.66 & 0.267 & 0.9956 \\
\hline 2 & Up & 1 & -11.66 & 11.97 & 0.268 & 0.9972 \\
\hline & & 2 & -12.12 & 12.02 & 0.268 & 0.9973 \\
\hline 2 & Down & 1 & 5.28 & 1.91 & 0.476 & 0.9968 \\
\hline & & 2 & 4.63 & 2.19 & 0.457 & 0.9965 \\
\hline
\end{tabular}


The Bingham Plastic model was fitted between 400 to $2000 \mathrm{sec}^{-1}$ for sample data. This data can be used for scoping engineering calculations. The Power Law models were fitted to the complete shear range and can be used for scoping engineering calculations.

The Herschel-Bulkley models were fitted to the complete shear range. An issue with these results is if the Herschel-Bulkley model yields a negative number, one must revert back to the Power Law model results. The Haake Software does not place a lower bound of zero for the Herschel-Bulkley model. These results can be used for scoping engineering calculations.

\section{$\underline{\text { Simulant Validation Protocol }}$}

Simulants will be used in testing and demonstrations for each option and/or unit operation being investigated. To be successful, the simulant must adequately reflect those properties of the waste stream that impact the system being investigated. For example, if a pump will be used to transfer slurry, then a simulant should be developed to mimic the physical properties of the slurry (rheological properties of yield stress and viscosity, solids loading, particle size distribution, and settling rate). The results of the testing are evaluated and conclusions drawn based on the fact that the simulant adequately represents and/or conservatively bounds the actual waste streams. The process by which assurance is gained that the simulant adequately represents actual waste is referred to as Simulant Validation.

The initial step of the Simulant Validation process is to define the properties of the actual waste stream required for the demonstration or unit testing (this may require acquisition of additional data). The next step is to establish acceptance criteria for these simulant properties that will conservatively bound the expected operational conditions. The simulant developed for the testing must meet these acceptance criteria by demonstration (e.g., measure the rheological properties of the simulant). Once the acceptance criteria are met, the simulant is validated.

The simulant may or may not have to be chemically equivalent to the actual waste. Normally, if chemical equivalence is achievable, then it is best to produce a simulant that matches as closely as possible the chemical composition of the actual waste.

Minor chemical constituents may be included or excluded depending upon the specific objectives of the testing. For example, RCRA metals may be included if the waste form produced by the process must meet TCLP, a requirement that is not currently part of Idaho's strategy. Elements regulated for off-gas may also be included so that data obtained during the demonstration can confirm compliance with regulations. One strategy is to include the most volatile element(s) for off-gas compliance or the RCRA metal(s) that is anticipated to give the greatest challenge in meeting TCLP instead of including all RCRA metals and all minor volatile components.

For simulant development, it is essential that simulant requirements and acceptance criteria be agreed upon by those involved in the demonstrations. That is, there must be 
coincidence between the simulant properties required and the testing that will be performed. This is a joint effort with all affected member of the team involved.

For steam reforming, the process requires a simulant that matches to some degree both the physical and chemical properties of the waste stream. It is expected that the simulant be validated, within the specifications for acceptance criteria, for particle size distribution, settling rates, yield stress, consistency (viscosity) and insoluble solids loading in the slurry. On the chemical side, the goal will be to simulate as closely as possible the actual waste to ensure that the chemistry that occurs in the reformer does not produce processing problems or a non-compliant waste form. Since the solids will be blended with the liquid SBW, it may be necessary to introduce RCRA metals and regulated off-gas elements (or suitable representatives) into only one of the phases. The mineral phase is also of importance to the simulant since the phase can also play a role in the reformer chemistry.

Similar requirements can also be presented for the other options under consideration. However, the final selection of properties to be simulated and their acceptance criteria will need to be decided by the parties involved in the down-select process (operations, regulatory requirements for off-gas, waste form performance, etc).

\section{Conclusions}

- The chemical and radiochemical compositions of WM-182 and WM-183 insoluble solids have been approximated by subtraction of the soluble solids from the total solids. The contribution of the soluble solids to the measured total solids was on the order of $30 \mathrm{wt} \%$. This action removed the nitrate as a component of the insoluble solids.

- These calculations also show that approximately half of the radioactivity from Tank WM-183 total solids is associated with the soluble radionuclides from the supernate. On the other hand, only $10 \%$ of radioactivity from WM-182 total solids is associated with soluble radionuclides from the supernate.

- Charge balance was a problem due to the very high level of phosphate measured in the WM-183 solids. At this stage, calcium was added to charge balance the analytical results. However, a consequence of this was that the resultant simulant had much more calcium than was actually detected in the solids.

- OLI modeling was applied to this system using the available supernate data for WM183 and the solids data, modified to achieve charge balance, for WM-183. The model predicted the presence of several solids including silica, zirconia, and iron phosphate and revealed the problem with excess phosphate.

- An initial simulant (at two different acid concentrations) was developed, fabricated, and characterized. This simulant is a baseline simulant to which changes can be 
made as requirements are finalized and additional data (XRD and SEM on solids and results of 'washing' of the radioactive tank sample) obtained. Particle size distribution and rheology measurements were measured on the simulants.

- After subtraction of the supernate contribution to RCRA metals, it was determined that the major RCRA metals in the insoluble solids from Tank WM-183 were $\mathrm{Cr}, \mathrm{Ni}$, and $\mathrm{Ag}$ and from Tank WM-182 were $\mathrm{As}, \mathrm{Cr}, \mathrm{Ni}$, and $\mathrm{Zn}$. It appears that $\mathrm{Hg}$ presence in the tank solids sample originated mainly from the supernate.

- A validation process was suggested and can be accomplished once simulant requirements are finalized and acceptance criteria established.

- A path forward was proposed that would lead to final simulants for the testing and demonstrations to be performed as part of the down-selection process.

\section{$\underline{\text { Path Forward }}$}

- Establish the requirements needed for simulants for each option and define the acceptance criteria that the simulant will have to meet (for simulant validation). This is an important step that must involve the input from and the buy-in of the people involved in each aspect of the testing and demonstrations.

- Obtain the necessary chemical and mineralogical phases of the solids through XRD and SEM measurements of actual samples that are consistent with the simulant requirements established in the previous bullet.

- Determine the effect of solids 'washing' on the physical and chemical properties of the solids of actual samples, consistent with the simulant requirements established in the first bullet.

- Measure the rheological and physical properties of the 'washed' solids from the actual samples to obtain the basis data on which to validate the simulant (again, consistent with the simulant requirements established in the first bullet).

- Obtain confirmation that the waste forms produced by the four options will have no leaching performance requirements, i.e., the waste form will meet the WIPP WAC).

- Establish which elements are required in the solids to confirm through planned testing in the demonstrations, that regulatory emission requirements are met.

- Define and prepare a refined simulant(s) that is consistent with both the physical and chemical simulant requirements established in the first bullet.

- Validate this simulant against the acceptance criteria. 


\section{$\underline{\text { References: }}$}

1. J. D. Christian, "Worst Case Simulant for INTEC Sodium-Bearing Waste Vitrification Tests", INEEL/EXT-01-01219, September 2001.

2. A. Poloski and M. Wilcox, "Solids Characterization, EDF-TST-001, Rev. 0, September, 2000.

3. C. M. Barnes and J. J. Quigley, "Tank Heel Solids Processing Methods Assessment”, EDF-1736, Rev. 0, January 2001.

4. From C. M. Barnes, “Tank Farm Composition Database” Rev 0, July 1999.

5. C. M. Barnes, R. A. Wood, B. H. O'Brien, "Process Design of SBW Alternatives", EDF-2373, September 2002 


\section{ATTACHMENT 1 OLI SIMULATION OF TANK WM-183 CHEMISTRY}

The aqueous chemistry of Tank WM-183 at INEEL was simulated using the OLI Analyzer version 1.2, licensed by OLI Systems, Inc. Specifically, the goal of this electrolyte simulation was to demonstrate the effectiveness of the OLI software tool in predicting the equilibrium speciation of various aqueous, solid and, if any, gaseous species in a complicated multicomponent system. Available analytical data shown in Table 1 for the $2.33 \mathrm{ml}$ Tank WM-183 slurry sample were the basis for doing so. Table 1 contains the elemental and ionic data for the supernate and air-dried solid residue but does not provide any data for the insoluble solids. It was, therefore, necessary to make appropriate assumptions regarding the solid phase prior to any modeling attempt and later to confirm those assumptions against the model predictions.

TABLE 1. Analytical Data for $2.33 \mathrm{ml}$ Tank WM-183 Slurry Sample.

\begin{tabular}{|lccc|}
\hline Species & FW & $\begin{array}{c}\text { supernate } \\
\mathbf{m g} / \mathbf{k g}\end{array}$ & $\begin{array}{c}\text { air-dried } \\
\mathbf{m g} / \mathbf{k g}\end{array}$ \\
\hline $\mathrm{Al}$ & 26.981538 & $9.6684 \mathrm{E}+03$ & $2.49 \mathrm{E}+04$ \\
$\mathrm{~B}$ & 10.811 & $8.1083 \mathrm{E}+01$ & $1.82 \mathrm{E}+02$ \\
$\mathrm{Ca}$ & 40.078 & $8.6836 \mathrm{E}+02$ & $1.87 \mathrm{E}+03$ \\
$\mathrm{Fe}$ & 55.8457 & $1.5823 \mathrm{E}+03$ & $1.80 \mathrm{E}+04$ \\
$\mathrm{~K}$ & 39.0983 & $2.2482 \mathrm{E}+03$ & $1.09 \mathrm{E}+04$ \\
$\mathrm{Mg}$ & 24.305 & $1.6203 \mathrm{E}+02$ & $4.34 \mathrm{E}+02$ \\
$\mathrm{Mn}$ & 54.938049 & $3.7541 \mathrm{E}+02$ & $7.40 \mathrm{E}+02$ \\
$\mathrm{Mo}$ & 95.94 & $4.4772 \mathrm{E}+01$ & $6.94 \mathrm{E}+02$ \\
$\mathrm{Nb}$ & 92.90638 & $3.7163 \mathrm{E}+00$ & $6.23 \mathrm{E}+02$ \\
$\mathrm{Si}$ & 28.0855 & $7.4895 \mathrm{E}+01$ & $3.53 \mathrm{E}+04$ \\
$\mathrm{Na}$ & 22.98977 & $1.0537 \mathrm{E}+04$ & $2.14 \mathrm{E}+04$ \\
$\mathrm{Sn}$ & 118.71 & $1.0882 \mathrm{E}+00$ & $1.47 \mathrm{E}+03$ \\
$\mathrm{Ti}$ & 47.867 & $1.9147 \mathrm{E}+00$ & $7.11 \mathrm{E}+02$ \\
$\mathrm{Zr}$ & 91.224 & $8.3622 \mathrm{E}+01$ & $3.49 \mathrm{E}+04$ \\
$\mathrm{Cl}$ & 35.4527 & $2.4226 \mathrm{E}+02$ & $1.31 \mathrm{E}+03$ \\
$\mathrm{~F}$ & 18.9984032 & $5.8578 \mathrm{E}+02$ & $4.37 \mathrm{E}+03$ \\
$\mathrm{NO}$ & 62.01 & $1.4468 \mathrm{E}+05$ & $1.75 \mathrm{E}+05$ \\
$\mathrm{PO} 4$ & 94.97 & $2.3664 \mathrm{E}+01$ & $1.26 \mathrm{E}+05$ \\
$\mathrm{SO} 4$ & 96.07 & $1.7612 \mathrm{E}+03$ & $1.36 \mathrm{E}+04$ \\
& & & \\
$\mathrm{TOTAL}$ & & $1.7302 \mathrm{E}+05$ & $4.7240 \mathrm{E}+05$ \\
\hline
\end{tabular}

\begin{tabular}{|lr|}
\hline volume of slurry sample $(\mathrm{ml})=$ & 2.33 \\
weight of slurry sample $(\mathrm{g})=$ & 2.906 \\
measured supernate density $(\mathrm{g} / \mathrm{ml})=$ & 1.2 \\
mass of air dried sample $(\mathrm{g})=$ & 1.179 \\
initial $\mathrm{H}+$ in supernate $(\mathrm{M})=$ & 2.5 \\
\hline
\end{tabular}

\section{Construction of Model Input}

The input to the OLI model must be in a neutral species form. This required conversion of the elemental and ionic concentrations given in Table 1 into those based on neutral species. In doing so, the slurry sample was conceptually divided into the supernate and the remaining solid phase, and the composition of each phase was developed separately. Table 2 and 3 show the resulting composition of Tank WM- 183 supernate and insoluble solids, respectively. Two key bases or assumptions used were: 
- The concentration of $\mathrm{H}^{+}$was varied to achieve the charge balance in the supernate phase, rather than fixing it at the measured value of $2.5 \mathrm{M}$.

- The density of insoluble solids was set at $2.5 \mathrm{~g} / \mathrm{ml}$.

TABLE 2. Estimated Composition of WM-183 Supernate.

\begin{tabular}{|c|c|c|c|c|c|}
\hline Species & MW & Conc (M) & g/liter & sample (g) & sample (mol) \\
\hline $\mathrm{NaNO} 3$ & 85 & 4.5235E-01 & $3.8450 \mathrm{E}+01$ & 8.4840E-02 & $9.9812 \mathrm{E}-04$ \\
\hline $\mathrm{Na} 2 \mathrm{SO} 4$ & 142.04 & 2.1156E-02 & $3.0049 \mathrm{E}+00$ & 6.6304E-03 & 4.6680E-05 \\
\hline $\mathrm{NaF}$ & 41.99 & 3.6316E-02 & $1.5249 \mathrm{E}+00$ & 3.3647E-03 & $8.0131 \mathrm{E}-05$ \\
\hline $\mathrm{NaCl}$ & 58.443 & 8.0489E-03 & 4.7040E-01 & 1.0379E-03 & $1.7760 \mathrm{E}-05$ \\
\hline $\mathrm{Na3PO} 4$ & 163.944 & $2.9349 \mathrm{E}-04$ & 4.8116E-02 & 1.0617E-04 & $6.4760 \mathrm{E}-07$ \\
\hline HNO3 & 63 & 7.7824E-01 & $4.9029 \mathrm{E}+01$ & 1.0818E-01 & $1.7172 \mathrm{E}-03$ \\
\hline $\mathrm{Al}(\mathrm{NO} 3) 3$ & 212.98154 & $4.2208 \mathrm{E}-01$ & $8.9895 E+01$ & 1.9836E-01 & $9.3133 \mathrm{E}-04$ \\
\hline $\mathrm{B}(\mathrm{OH}) 3$ & 61.81 & 8.8351E-03 & $5.4610 \mathrm{E}-01$ & 1.2050E-03 & $1.9495 \mathrm{E}-05$ \\
\hline $\mathrm{Ca}(\mathrm{NO} 3) 2$ & 164.08 & $2.5520 \mathrm{E}-02$ & $4.1873 \mathrm{E}+00$ & 9.2393E-03 & $5.6310 \mathrm{E}-05$ \\
\hline $\mathrm{Fe}(\mathrm{NO} 3) 3$ & 241.847 & 3.3373E-02 & $8.0712 \mathrm{E}+00$ & 1.7809E-02 & 7.3638E-05 \\
\hline KNO3 & 101.0983 & $6.7729 \mathrm{E}-02$ & $6.8473 \mathrm{E}+00$ & 1.5109E-02 & 1.4945E-04 \\
\hline $\mathrm{Mg}(\mathrm{NO} 3) 2$ & 148.305 & 7.8527E-03 & $1.1646 \mathrm{E}+00$ & 2.5697E-03 & 1.7327E-05 \\
\hline $\mathrm{Mn}(\mathrm{NO} 3) 2$ & 178.938 & $8.0490 \mathrm{E}-03$ & $1.4403 \mathrm{E}+00$ & $3.1780 \mathrm{E}-03$ & $1.7760 \mathrm{E}-05$ \\
\hline $\mathrm{MoO} 2(\mathrm{NO} 3) 2$ & 251.94 & $5.4969 \mathrm{E}-04$ & 1.3849E-01 & 3.0558E-04 & 1.2129E-06 \\
\hline $\mathrm{Sn}(\mathrm{NO} 3) 2$ & 242.69 & 1.0799E-05 & 2.6209E-03 & 5.7830E-06 & 2.3829E-08 \\
\hline $\mathrm{Nb2O5}$ & 265.812 & 4.7116E-05 & 1.2524E-02 & 2.7634E-05 & 1.0396E-07 \\
\hline $\mathrm{Si}(\mathrm{OH}) 4$ & 96.11498 & $3.1411 \mathrm{E}-03$ & 3.0190E-01 & 6.6615E-04 & $6.9308 \mathrm{E}-06$ \\
\hline TiO2 & 79.9 & 4.7084E-05 & 3.7620E-03 & 8.3008E-06 & $1.0389 \mathrm{E}-07$ \\
\hline $\mathrm{ZrO} 2$ & 123.224 & $1.0798 \mathrm{E}-03$ & 1.3306E-01 & 2.9359E-04 & 2.3826E-06 \\
\hline $\mathrm{H} 2 \mathrm{O}$ & 18.02 & & $9.7263 \mathrm{E}+02$ & $2.1461 \mathrm{E}+00$ & 1.1910E-01 \\
\hline Total & & & $1.1779 \mathrm{E}+03$ & $2.5990 \mathrm{E}+00$ & 1.2323E-01 \\
\hline
\end{tabular}

Both the supernate density and the volume fraction of insoluble solids in the slurry sample were iterated until the mass of insoluble solids calculated from the overall mass balance matched that derived from the component mass balance given in Table 3. The insoluble fractions of each element and ion were estimated simply by subtracting the soluble mass of each element and ion in the supernate from the corresponding mass in the air-dried sample, assuming that no significant quantity of moisture was left in the air-dried sample. It turned out that nitrate was the only element or ion that exhibited any "significantly negative" insoluble fraction mostly likely due to the volatilization of nitric acid.

One major difficulty encountered during the development of insoluble solids composition shown in Table 3 was the fact that the projected concentration of cations in the insoluble solid phase was nowhere near what was needed to counterbalance the excessively high concentration of phosphate measured in the air-dried sample. It can be seen from Table 1 that nitrate and phosphate are two most abundant species in Tank WM183 , and yet nearly $100 \%$ of the phosphate was measured to be insoluble, even more so than $\mathrm{Si}$ or $\mathrm{Zr}$. As a result, the large quantity of excess phosphate was forced to form pentoxide, $\left(\mathrm{P}_{2} \mathrm{O}_{5}\right)_{2}$ just to maintain both charge and mass balances. However, pentoxide would not form under the actual tank conditions, since it readily turns into phosphate in the presence of water. The phase identification of phosphorus in Tank WM183 is one of the primary goals of this modeling study. 
The resulting concentration of $\mathrm{H}^{+}$that would give the charge balance in the supernate phase was $0.78 \mathrm{M}$, which is considerably lower than the measured value of $2.5 \mathrm{M}$. The reason for not using the measured $\mathrm{H}^{+}$ concentration in the first place was the fact that there were just not enough anions available to counterbalance the cations at $2.5 \mathrm{M} \mathrm{H}^{+}$. The converged values of supernate density and insoluble solids volume fraction were $1.1778 \mathrm{~g} / \mathrm{ml}$ and 0.053 , respectively. It is noted that if the estimated supernate density were to be rounded off to the nearest tenth, it would match the measured value of $1.2 \mathrm{~g} / \mathrm{ml} \mathrm{exactly}$. The final confirmation of the estimated supernate density and insoluble solids volume fraction will be made later against the OLI model results.

TABLE 3. Estimated Composition of WM-183 Insoluble Solids.

\begin{tabular}{|c|c|c|c|}
\hline & FW & sample (g) & sample (mole) \\
\hline $\mathrm{Al}(\mathrm{NO} 3) 3.9 \mathrm{H} 2 \mathrm{O}$ & 374.98154 & & \\
\hline $\mathrm{Na} 2 \mathrm{SO} 4$ & 142.04 & & \\
\hline CaSO4 & 136.15 & & \\
\hline $\mathrm{Fe} 2(\mathrm{SO} 4) 3$ & 399.9014 & 1.5897E-02 & 3.9752E-05 \\
\hline KNO3 & 101.0983 & & \\
\hline $\mathrm{SiO} 2$ & 60.0855 & 8.8622E-02 & 1.4749E-03 \\
\hline NaNO3 & 85 & & \\
\hline $\mathrm{Sn}(\mathrm{NO} 3) 2$ & 242.69 & & \\
\hline TiO2 & 233.9 & & \\
\hline $\mathrm{ZrO2}$ & 123.224 & 4.9402E-02 & 4.0091E-04 \\
\hline $\mathrm{NaCl}$ & 58.44 & & \\
\hline ZrF4 & 167.2176 & 7.9870E-03 & 4.7764E-05 \\
\hline $\mathrm{NaF}$ & 41.99 & & \\
\hline AIPO4 & 121.9529 & 1.9112E-02 & $1.5672 \mathrm{E}-04$ \\
\hline K3PO4 & 212.2663 & 1.2682E-02 & 5.9747E-05 \\
\hline $\mathrm{Na3PO} 4$ & 163.944 & & \\
\hline FePO4 & 150.8184 & 3.4216E-02 & 2.2687E-04 \\
\hline Ca3(PO4)2 & 310.18 & & \\
\hline (P2O5)2 & 283.889 & 7.9501E-02 & 2.8004E-04 \\
\hline Total & & 3.0742E-01 & 2.6867E-03 \\
\hline
\end{tabular}

\section{OLI Model Run}

The sample mass or molar flows of each species given in Tables 2 and 3 for the supernate and insoluble solid phases, respectively, constituted the input to the OLI model. The model was run at $25^{\circ} \mathrm{C}$ and 1 atm in conjunction with the software default database PUBLIC v6.6 and the private database, called HNO3DB, which was developed recently for the Na-K-Cs-Al- $\mathrm{HNO}_{3}-\mathrm{H}_{2} \mathrm{O}$ system using both SRTC and literature data. For the feed chemistry described in Tables 2 and 3, the resulting OLI model of Tank WM-183 chemistry considered a total of 315 species, consisting of 138 aqueous, 168 solid and 9 vapor species, as shown in Table 4. 
TABLE 4. Aqueous, Solid and Vapor Species in the WM-183 Chemistry Model.

\begin{tabular}{|c|c|c|c|c|c|c|}
\hline Aqueous & & & Solids & & & \\
\hline $\mathrm{H} 2 \mathrm{O}$ & $(\mathrm{HF}) 2-\mathrm{Aq}$ & $\mathrm{HNO}-\mathrm{Aq}$ & $\mathrm{Al}(\mathrm{OH}) 2 \mathrm{Cl}$ & $\mathrm{Fe} 2(\mathrm{SO} 4) 3$ & $\mathrm{KF} .4 \mathrm{H} 2 \mathrm{O}$ & $\mathrm{Na} 3 \mathrm{PO} 4.6 \mathrm{H} 2 \mathrm{O}$ \\
\hline $\mathrm{Al}(\mathrm{OH}) 2 \mathrm{Cl}-\mathrm{Aq}$ & $\mathrm{HCl}-\mathrm{Aq}$ & $\mathrm{H} 3 \mathrm{PO} 4$ - Aq & $\mathrm{AlCl} 3.6 \mathrm{H} 2 \mathrm{O}$ & $\mathrm{MgCl} 2$ & K2SiF6 & $\mathrm{Na} 3 \mathrm{PO} 4.0 .25 \mathrm{NaOH} .12 \mathrm{H} 2 \mathrm{O}$ \\
\hline $\mathrm{AlOHCl}+1$ & HF2-1 & $\mathrm{PO} 4-3$ & $\mathrm{AlOHCl} 2$ & $\mathrm{MgCl} 2.2 \mathrm{H} 2 \mathrm{O}$ & $\mathrm{K} 2 \mathrm{HPO} 4.6 \mathrm{H} 2 \mathrm{O}$ & $\mathrm{Na} 3 \mathrm{PO} 4.1 \mathrm{H} 2 \mathrm{O}$ \\
\hline AlF2+1 & $\mathrm{HF}-\mathrm{Aq}$ & $\mathrm{KHSO} 4-\mathrm{Aq}$ & AlF3.3H2O & $\mathrm{MgCl} 2.6 \mathrm{H} 2 \mathrm{O}$ & K2HPO4.3H2O & $\mathrm{Na} 3 \mathrm{PO} 4.8 \mathrm{H} 2 \mathrm{O}$ \\
\hline $\mathrm{Al}(\mathrm{OH}) 2+1$ & HSiF6-1 & $\mathrm{KCl}-\mathrm{Aq}$ & $\mathrm{Al}(\mathrm{OH}) 3$ & $\mathrm{MgClOH}$ & K2HPO4 & $\mathrm{NaB} 5 \mathrm{O} 8.5 \mathrm{H} 2 \mathrm{O}$ \\
\hline $\mathrm{Al}(\mathrm{SO} 4) 2-1$ & HZrF6-1 & $\mathrm{K}+1$ & $\mathrm{AL}(\mathrm{NO} 3) 3.6 \mathrm{H} 2 \mathrm{O}$ & $\mathrm{MgCl} 2.4 \mathrm{H} 2 \mathrm{O}$ & $\mathrm{KOH}$ & 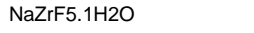 \\
\hline AlF3 - Aq & $\mathrm{H}+1$ & $\mathrm{KNO} 3-\mathrm{Aq}$ & $\mathrm{Al}(\mathrm{NO} 3) 3.9 \mathrm{H} 2 \mathrm{O}$ & $\mathrm{MgF} 2$ & $\mathrm{KOH} .2 \mathrm{H} 2 \mathrm{O}$ & $\mathrm{Na} 4 \mathrm{P} 2 \mathrm{O} 7.10 \mathrm{H} 2 \mathrm{O}$ \\
\hline AlF6-3 & HPO4-2 & KSO4-1 & $\mathrm{Al}(\mathrm{NO} 3) 3.8 \mathrm{H} 2 \mathrm{O}$ & $\mathrm{Mg}(\mathrm{OH}) 2$ & $\mathrm{KOH} .1 \mathrm{H} 2 \mathrm{O}$ & $\mathrm{Na} 4 \mathrm{P} 2 \mathrm{O} 7$ \\
\hline $\mathrm{Al}(\mathrm{OH}) 3-\mathrm{Aq}$ & HP2O7-3 & $\mathrm{P} 2 \mathrm{O} 7-4$ & $\mathrm{AlO}(\mathrm{OH})$ & $\mathrm{Mg}(\mathrm{NO} 3) 2.6 \mathrm{H} 2 \mathrm{O}$ & $\mathrm{KMgCl} 3$ & $\mathrm{Na} 2 \mathrm{SO} 4$ \\
\hline $\mathrm{Al}+3$ & $\mathrm{OH}-1$ & $\mathrm{H} 4 \mathrm{P} 2 \mathrm{O} 7$ - Aq & AIPO4 & $\mathrm{Mg}(\mathrm{NO} 3) 2$ & $\mathrm{KMgCl} 3.2 \mathrm{H} 2 \mathrm{O}$ & $\mathrm{Na} 2 \mathrm{SO} 4$ \\
\hline $\mathrm{AlF}+2$ & $\mathrm{FeCl} 3-\mathrm{Aq}$ & $\mathrm{SiO} 2-\mathrm{Aq}$ & $\mathrm{Al} 2(\mathrm{SO} 4) 3$ & $\mathrm{Mg}(\mathrm{NO} 3) 2.2 \mathrm{H} 2 \mathrm{O}$ & KBO2 & $\mathrm{Na} 2 \mathrm{SO} 4 . \mathrm{NaHSO} 4$ \\
\hline $\mathrm{AlOH}+2$ & $\mathrm{Fe}+3$ & $\mathrm{SiCl} 4-\mathrm{Aq}$ & $\mathrm{Al} 2(\mathrm{SO} 4) 3.16 \mathrm{H} 2 \mathrm{O}$ & $\mathrm{Mg} 3(\mathrm{PO} 4) 2$ & KNO3 & $\mathrm{Na} 2 \mathrm{SO} 4.10 \mathrm{H} 2 \mathrm{O}$ \\
\hline AlSO4+1 & $\mathrm{FeCl} 2+1$ & $\mathrm{NaB}(\mathrm{OH}) 4-\mathrm{Aq}$ & $\mathrm{Al} 2(\mathrm{SO} 4) 3.6 \mathrm{H} 2 \mathrm{O}$ & $\mathrm{Mg} 3(\mathrm{PO} 4) 2.8 \mathrm{H} 2 \mathrm{O}$ & K3PO4 & $\mathrm{Na} 2 \mathrm{~B} 4 \mathrm{O} 7$ \\
\hline AlF5-2 & $\mathrm{FeF} 2+1$ & $\mathrm{NaF}-\mathrm{Aq}$ & $\mathrm{B}(\mathrm{OH}) 3$ & $\mathrm{MgSO} 4$ & K3PO4.7H2O & $\mathrm{Na} 2 \mathrm{~B} 4 \mathrm{O} 7.10 \mathrm{H} 2 \mathrm{O}$ \\
\hline AlF4-1 & $\mathrm{FeH} 2 \mathrm{PO} 4+2$ & $\mathrm{NaHSiO} 3-\mathrm{Aq}$ & $\mathrm{CaCl} 2$ & $\mathrm{MgSO} 4.7 \mathrm{H} 2 \mathrm{O}$ & K3PO4.3H2O & $\mathrm{Na} 2 \mathrm{~B} 4 \mathrm{O} 7.5 \mathrm{H} 2 \mathrm{O}$ \\
\hline $\mathrm{Al}(\mathrm{OH}) 4-1$ & $\mathrm{Fe}(\mathrm{OH}) 2+1$ & $\mathrm{Na}+1$ & $\mathrm{CaCl} 2.2 \mathrm{H} 2 \mathrm{O}$ & $\mathrm{MgSO} 4.6 \mathrm{H} 2 \mathrm{O}$ & $\mathrm{K} 2 \mathrm{SO} 4$ & $\mathrm{Na} 2 \mathrm{~B} 4 \mathrm{O} 7.4 \mathrm{H} 2 \mathrm{O}$ \\
\hline HSO4-1 & $\mathrm{FeF} 3-\mathrm{Aq}$ & $\mathrm{NaNO} 3-\mathrm{Aq}$ & $\mathrm{CaCl} 2.6 \mathrm{H} 2 \mathrm{O}$ & $\mathrm{MgSO} 4.1 \mathrm{H} 2 \mathrm{O}$ & $\mathrm{K} 2 \mathrm{SO} 4.1 \mathrm{H} 2 \mathrm{O}$ & NaBF4 \\
\hline $\mathrm{B}(\mathrm{OH}) 3-\mathrm{Aq}$ & FeHPO4+1 & $\mathrm{NaSO} 4-1$ & $\mathrm{CaCl} 2 . \mathrm{H} 2 \mathrm{O}$ & $\mathrm{Mg} 1.25(\mathrm{SO} 4)(\mathrm{OH}) 0.5 .0 .5 \mathrm{H} 2 \mathrm{O}$ & KBF4 & ZrF4 \\
\hline $\mathrm{BF} 2(\mathrm{OH}) 2-1$ & $\mathrm{Fe}(\mathrm{OH}) 3-\mathrm{Aq}$ & SO4-2 & $\mathrm{CaCl} 2 . \mathrm{CaO} .2 \mathrm{H} 2 \mathrm{O}$ & $\mathrm{Mg} 1.5(\mathrm{SO} 4)(\mathrm{OH})$ & $\mathrm{SiO} 2$ & $\mathrm{ZrF} 4.1 \mathrm{H} 2 \mathrm{O}$ \\
\hline $\mathrm{BF} 3 \mathrm{OH}-1$ & $\mathrm{FeCl} 2+2$ & $\mathrm{SO} 3-\mathrm{Aq}$ & $\mathrm{CaCl} 2.4 \mathrm{H} 2 \mathrm{O}$ & $\mathrm{MnCl} 2$ & $\mathrm{NaALO} 2$ & $\mathrm{ZrF} 4.3 \mathrm{H} 2 \mathrm{O}$ \\
\hline BF4-1 & $\mathrm{FeF}+2$ & $\mathrm{H} 2 \mathrm{SO} 4-\mathrm{Aq}$ & $\mathrm{Ca}(\mathrm{H} 2 \mathrm{PO} 4) 2$ & $\mathrm{MnCl} 2.2 \mathrm{H} 2 \mathrm{O}$ & $\mathrm{Na} 2 \mathrm{O} . \mathrm{Al} 2 \mathrm{O} 3.2 .5 \mathrm{H} 2 \mathrm{O}$ & $\mathrm{ZrO} 2$ \\
\hline $\mathrm{B}(\mathrm{OH}) 4-1$ & $\mathrm{FeOH}+2$ & $\mathrm{~B} 4 \mathrm{O} 5(\mathrm{OH}) 4-2$ & $\mathrm{Ca}(\mathrm{H} 2 \mathrm{PO} 4) 2.1 \mathrm{H} 2 \mathrm{O}$ & $\mathrm{MnCl} 2.1 \mathrm{H} 2 \mathrm{O}$ & $\mathrm{NaHSO} 4$ & $\mathrm{ZrOCl} 2$ \\
\hline $\mathrm{BF}(\mathrm{OH}) 3-1$ & $\mathrm{FeNO} 3+2$ & HBF4 - Aq & $\mathrm{CaF} 2$ & $\mathrm{MnCl} 2.4 \mathrm{H} 2 \mathrm{O}$ & $\mathrm{NaCl}$ & ZrOCL2.3.5H2O \\
\hline $\mathrm{CaCl} 2-\mathrm{Aq}$ & $\mathrm{FeSO} 4+1$ & $\mathrm{SiF} 4$ - Aq & CaHPO4 & MnF2 & $\mathrm{NaH} 2 \mathrm{PO} 4.2 \mathrm{H} 2 \mathrm{O}$ & $\mathrm{ZrOCl} 2.2 \mathrm{H} 2 \mathrm{O}$ \\
\hline $\mathrm{CaH} 2 \mathrm{BO} 3+1$ & $\mathrm{FeCl} 4-1$ & $\mathrm{~B} 3 \mathrm{O} 3(\mathrm{OH}) 4-1$ & $\mathrm{CaHPO} 4.2 \mathrm{H} 2 \mathrm{O}$ & $\mathrm{MnF} 2.4 \mathrm{H} 2 \mathrm{O}$ & $\mathrm{NaH} 2 \mathrm{PO} 4.1 \mathrm{H} 2 \mathrm{O}$ & $\mathrm{ZrOCl} 2.6 \mathrm{H} 2 \mathrm{O}$ \\
\hline $\mathrm{CaH} 2 \mathrm{PO} 4+1$ & $\mathrm{Fe}(\mathrm{OH}) 4-1$ & H3P2O7-1 & $\mathrm{Ca}(\mathrm{OH}) 2$ & $\mathrm{Mn}(\mathrm{OH}) 2$ & $\mathrm{NaH} 2 \mathrm{PO} 4$ & $\mathrm{ZrOCl} 2.8 \mathrm{H} 2 \mathrm{O}$ \\
\hline CaHSiO3+1 & $\mathrm{MgH} 2 \mathrm{PO} 4+1$ & $\mathrm{H} 3 \mathrm{SiO} 4-1$ & $\mathrm{Ca}(\mathrm{NO} 3) 2$ & $\mathrm{Mg}(\mathrm{NO} 3) 2.6 \mathrm{H} 2 \mathrm{O}$ & $\mathrm{NaF}$ & $\mathrm{Zr}(\mathrm{SO} 4) 2$ \\
\hline $\mathrm{CaOH}+1$ & $\mathrm{MgSiO} 2(\mathrm{OH}) 2-\mathrm{Aq}$ & $\mathrm{ZrCl} 2+2$ & $\mathrm{Ca}(\mathrm{NO} 3) 2.4 \mathrm{H} 2 \mathrm{O}$ & $\mathrm{Mn}(\mathrm{NO} 3) 2.1 \mathrm{H} 2 \mathrm{O}$ & NaF.Na2SO4 & $\mathrm{ZrSO} 42.1 \mathrm{H} 2 \mathrm{O}$ \\
\hline $\mathrm{Ca}+2$ & $\mathrm{MgHSiO} 3+1$ & $\mathrm{ZrF2+2}$ & $\mathrm{Ca}(\mathrm{NO} 3) 2.3 \mathrm{H} 2 \mathrm{O}$ & $\mathrm{Mn}(\mathrm{NO} 3) 2.4 \mathrm{H} 2 \mathrm{O}$ & Na2SiF6 & $\mathrm{Zr}(\mathrm{SO} 4) 2.4 \mathrm{H} 2 \mathrm{O}$ \\
\hline $\mathrm{CaCl}+1$ & $\mathrm{MgHPO} 4-\mathrm{Aq}$ & $\mathrm{Zr}(\mathrm{OH}) 2+2$ & $\mathrm{Ca} 3(\mathrm{BO} 3) 2$ & $\mathrm{Mn3}(\mathrm{PO} 4) 2$ & NaHF2 & $\mathrm{ZrCl} 4$ \\
\hline $\mathrm{CaF}+1$ & $\mathrm{MgOH}+1$ & $\mathrm{Zr}(\mathrm{NO} 3) 2+2$ & $\mathrm{Ca} 3(\mathrm{PO} 4) 2$ & $\mathrm{Mn} 3(\mathrm{PO} 4) 2.6 \mathrm{H} 2 \mathrm{O}$ & $\mathrm{Na} 2 \mathrm{HPO} 4$ & \\
\hline $\mathrm{Ca}(\mathrm{NO} 3)+1$ & $M g+2$ & $\mathrm{ZrF} 4-\mathrm{Aq}$ & $\mathrm{CaSO} 4$ & Mn3PO42.3H2O & $\mathrm{Na} 2 \mathrm{HPO} 4.2 \mathrm{H} 2 \mathrm{O}$ & \\
\hline CaPO4-1 & $\mathrm{MgF}+1$ & ZrF6-2 & $\mathrm{CaSO} 4.2 \mathrm{H} 2 \mathrm{O}$ & $\mathrm{MnSO} 4$ & $\mathrm{Na} 2 \mathrm{HPO} 4.12 \mathrm{H} 2 \mathrm{O}$ & \\
\hline $\mathrm{CaSiO} 2(\mathrm{OH}) 2-\mathrm{Aq}$ & $\mathrm{MgPO} 4-1$ & $\mathrm{Zr}(\mathrm{OH}) 4-\mathrm{Aq}$ & $\mathrm{Al} 2(\mathrm{OH}) 5 \mathrm{Cl}$ & $\mathrm{MnSO} 4.7 \mathrm{H} 2 \mathrm{O}$ & $\mathrm{Na} 2 \mathrm{HPO} 4.7 \mathrm{H} 2 \mathrm{O}$ & \\
\hline $\mathrm{CaSO} 4-\mathrm{Aq}$ & MgP2O7-2 & $\mathrm{Zr}+4$ & Na2ZrF6 & $\mathrm{MnSO} 4.1 \mathrm{H} 2 \mathrm{O}$ & $\mathrm{NaOH}$ & \\
\hline $\mathrm{Cl}-1$ & $\mathrm{MgSO} 4$ - Aq & $\mathrm{ZrCl}+3$ & $\mathrm{~K} 2 \mathrm{SO} 4 . \mathrm{KNaSO} 4$ & $\mathrm{MnSO} 4.5 \mathrm{H} 2 \mathrm{O}$ & $\mathrm{NaOH} .1 \mathrm{H} 2 \mathrm{O}$ & Vapor \\
\hline $\mathrm{B} 2 \mathrm{O}(\mathrm{OH}) 5-1$ & $\mathrm{Mn}+2$ & $\mathrm{ZrF}+3$ & $\mathrm{Na7F}(\mathrm{PO} 4) 2.19 \mathrm{H} 2 \mathrm{O}$ & Na5P3O10 & $\mathrm{NaBO} 2$ & \\
\hline H2SiF6 - Aq & $\mathrm{Mn}(\mathrm{OH}) 2-\mathrm{Aq}$ & $\mathrm{ZrOH}+3$ & $\mathrm{FeCl} 3$ & $\mathrm{Na} 5 \mathrm{P} 3 \mathrm{O} 10.6 \mathrm{H} 2 \mathrm{O}$ & $\mathrm{NABO} 2.2 \mathrm{H} 2 \mathrm{O}$ & $\mathrm{H} 2 \mathrm{O}$ - Vap \\
\hline $\mathrm{H} 2 \mathrm{PO} 4-1$ & $\mathrm{MnCl}+1$ & $\mathrm{ZrNO} 3+3$ & $\mathrm{FeCl} 3.2 .5 \mathrm{H} 2 \mathrm{O}$ & (P2O5)2 & $\mathrm{NaBO} 2.0 .5 \mathrm{H} 2 \mathrm{O}$ & $(\mathrm{HF}) 2$ - Vap \\
\hline $\mathrm{H} 2 \mathrm{SiO} 4-2$ & $\mathrm{Mn}(\mathrm{OH})+1$ & ZrF5-1 & $\mathrm{FeCl} 3.2 \mathrm{H} 2 \mathrm{O}$ & $\mathrm{KAl}(\mathrm{SO} 4) 2$ & $\mathrm{NaBO} 2.4 \mathrm{H} 2 \mathrm{O}$ & $\mathrm{HCl}$ - Vap \\
\hline H2P2O7-2 & $\mathrm{Mn}(\mathrm{NO} 3) 2-\mathrm{Aq}$ & $\mathrm{Zr}(\mathrm{OH}) 5-1$ & $\mathrm{FeCl} 3.6 \mathrm{H} 2 \mathrm{O}$ & $\mathrm{KAl}(\mathrm{SO} 4) 2.12 \mathrm{H} 2 \mathrm{O}$ & $\mathrm{Na} 2 \mathrm{SiO} 3$ & HF - Vap \\
\hline $\mathrm{Fe} 2(\mathrm{OH}) 2+4$ & $\mathrm{MnNO} 3+1$ & $\mathrm{ZrSO} 4+2$ & FeF3 & $\mathrm{KHSO} 4$ & $\mathrm{Na} 2 \mathrm{SiO} 3.6 \mathrm{H} 2 \mathrm{O}$ & HNO3 - Vap \\
\hline $\mathrm{Na} 2 \mathrm{~F}+1$ & $\mathrm{MnSO} 4$ - Aq & $\mathrm{ZrCl} 4-\mathrm{Aq}$ & $\mathrm{Fe}(\mathrm{OH}) 3$ & $\mathrm{KCl}$ & $\mathrm{Na} 2 \mathrm{SiO} 3.9 \mathrm{H} 2 \mathrm{O}$ & $\mathrm{SiCl} 4$ - Vap \\
\hline $\mathrm{F}-1$ & $\mathrm{Mn}(\mathrm{OH}) 4-2$ & $\mathrm{ZrCl} 3+1$ & $\mathrm{Fe}(\mathrm{NO} 3) 3.9 \mathrm{H} 2 \mathrm{O}$ & $\mathrm{KH} 2 \mathrm{PO} 4$ & $\mathrm{Na} 2 \mathrm{SiO} 3.5 \mathrm{H} 2 \mathrm{O}$ & SO3 - Vap \\
\hline SiF6-2 & $\mathrm{Mn}(\mathrm{OH}) 3-1$ & $\mathrm{ZrF3}+1$ & $\mathrm{FePO} 4$ & $\mathrm{KF}$ & $\mathrm{NaNO} 3$ & H2SO4 - Vap \\
\hline $\mathrm{H} 2 \mathrm{ZrF6}-\mathrm{Aq}$ & NO3-1 & $\mathrm{Zr}(\mathrm{OH}) 3+1$ & $\mathrm{FePO} 4.2 \mathrm{H} 2 \mathrm{O}$ & $\mathrm{KF} .2 \mathrm{H} 2 \mathrm{O}$ & $\mathrm{Na} 3 \mathrm{PO} 4$ & SiF4 - Vap \\
\hline
\end{tabular}




\section{OLI Model Results}

Some of the key model predictions are compared to the assumed values in Table 5.

Predicted densities of the solid and supernate phases are shown to match those assumed very well. The formation of four solid species, including $\mathrm{ZrO}_{2}, \mathrm{SiO}_{2}, \mathrm{FePO}_{4} \cdot 2 \mathrm{H}_{2} \mathrm{O}$ and $\mathrm{Zr}\left(\mathrm{SO}_{4}\right)_{2} \cdot 4 \mathrm{H}_{2} \mathrm{O}$, was predicted to be favorable under the Tank WM-183 conditions at the estimated $\mathrm{pH}$ of 1 . However, these predicted solid species would only add up to $64 \%$ of the total insoluble solids mass given in Table 3, which was derived from the mass and charge balances of the measured data given in Table 1 . The primary reason for this discrepancy is due to the fact that under the prescribed input conditions, the model predicted that $75 \%$ of the total phosphate in the tank would be soluble, compared to the data given in Table 1, which show that practically all phosphate would be insoluble. Table 6 shows all the phosphate species predicted by the model to be present in Tank WM-183 at any significant concentrations. It is noted that the predicted partitioning of phosphate is indeed consistent with the difficulty encountered earlier; That is, an unlikely insoluble species, pentoxide $\left(\mathrm{P}_{2} \mathrm{O}_{5}\right)_{2}$, had be created in Table 3 just to maintain both charge and mass balances in the solid phase. Therefore, it is concluded that the measured concentration of insoluble phosphate given in Table 1 may be in error, assuming that the data given for all the remaining species are accurate.

The full equilibrium speciation of the Tank WM-183 constituents is shown in Table 7 for all phases. The model predicted that no vapor species would form, since no air flow was added to the model as a carrier for the vapor species.

TABLE 5. Comparison of Assumed vs. Model Calculated Bulk Slurry Properties.

\begin{tabular}{lccc}
\hline & Assumed & Model & \% Difference \\
\hline Solid Density $(\mathrm{g} / \mathrm{ml})$ & 2.5 & 2.6 & 4 \\
Supernate Density $(\mathrm{g} / \mathrm{ml})$ & 1.1779 & 1.1666 & 1 \\
Insoluble Solids $(\mathrm{g})$ & 0.3074 & 0.1954 & 36 \\
$\begin{array}{l}\text { Insoluble Solids Volume }(\% \\
\text { Total) }\end{array}$ & 5.3 & 3.1 & 41 \\
\hline
\end{tabular}

TABLE 6. Phosphorus Containing Species in Tank WM-183 Predicted by the OLI Model.

\begin{tabular}{|lr|}
\hline & eqiv. $\mathrm{P}$ \\
& (mole \%) \\
$\mathrm{FePO}_{4} .2 \mathrm{H}_{2} \mathrm{O}(\mathrm{s})$ & 24.27 \\
$\mathrm{H}_{3} \mathrm{PO}_{4}$ & 65.75 \\
$\mathrm{H}_{4} \mathrm{P}_{2} \mathrm{O}_{7}$ & 0.20 \\
$\mathrm{H}_{2} \mathrm{PO}_{4}^{-1}$ & 8.46 \\
$\mathrm{H}_{2} \mathrm{P}_{2} \mathrm{O}_{7}^{-2}$ & 0.06 \\
$\mathrm{FeH}_{2} \mathrm{PO}_{4}{ }^{+2}$ & 0.03 \\
$\mathrm{MgH}_{2} \mathrm{PO}_{4}{ }^{+1}$ & 0.61 \\
$\mathrm{H}_{3} \mathrm{P}_{2} \mathrm{O}_{7}^{-1}$ & 0.08 \\
Total & 99.45 \\
\hline
\end{tabular}


TABLE 7. Calculated Composition of Tank WM-183 Slurry.

\begin{tabular}{|c|c|c|c|c|}
\hline Species Output (True Species) & $\begin{array}{l}\text { Slurry } \\
\text { (mole) }\end{array}$ & $\begin{array}{c}\text { Aqueous } \\
\text { (mole) }\end{array}$ & $\begin{array}{l}\text { Vapor } \\
\text { (mole) }\end{array}$ & $\begin{array}{l}\text { Solid } \\
\text { (mole) }\end{array}$ \\
\hline $\mathrm{H} 2 \mathrm{O}$ & 1.1699E-01 & 1.1699E-01 & & \\
\hline $\mathrm{NaNO} 3$ & 3.4791E-04 & $3.4791 \mathrm{E}-04$ & & \\
\hline $\mathrm{NaF}$ & $3.1089 \mathrm{E}-12$ & $3.1089 \mathrm{E}-12$ & & \\
\hline HNO3 & 7.9791E-06 & 7.9791E-06 & & \\
\hline $\mathrm{B}(\mathrm{OH}) 3$ & $1.9495 \mathrm{E}-05$ & 1.9495E-05 & & \\
\hline KNO3 & $1.2202 \mathrm{E}-04$ & $1.2202 \mathrm{E}-04$ & & \\
\hline $\mathrm{Mn}(\mathrm{NO} 3) 2$ & $6.4885 \mathrm{E}-06$ & $6.4885 \mathrm{E}-06$ & & \\
\hline $\mathrm{ZrO} 2$ & $5.0076 \mathrm{E}-05$ & & & 5.0076E-05 \\
\hline $\mathrm{SiO} 2$ & $1.4818 \mathrm{E}-03$ & 3.0677E-06 & & $1.4788 \mathrm{E}-03$ \\
\hline ZrF4 & $8.6820 \mathrm{E}-13$ & $8.6820 \mathrm{E}-13$ & & \\
\hline $\mathrm{Al}(\mathrm{OH}) 2 \mathrm{Cl}$ & $9.0635 E-32$ & $9.0635 \mathrm{E}-32$ & & \\
\hline AlF3 & $8.5453 \mathrm{E}-13$ & $8.5453 \mathrm{E}-13$ & & \\
\hline $\mathrm{Al}(\mathrm{OH}) 3$ & $2.2044 \mathrm{E}-18$ & $2.2044 \mathrm{E}-18$ & & \\
\hline $\mathrm{CaCl} 2$ & $1.0719 \mathrm{E}-28$ & 1.0719E-28 & & \\
\hline $\mathrm{CaSiO} 2(\mathrm{OH}) 2$ & $1.8690 \mathrm{E}-25$ & $1.8690 \mathrm{E}-25$ & & \\
\hline CaSO4 & $9.0189 \mathrm{E}-20$ & $9.0189 \mathrm{E}-20$ & & \\
\hline $\mathrm{H} 2 \mathrm{SiF} 6$ & $5.4079 \mathrm{E}-32$ & $5.4079 \mathrm{E}-32$ & & \\
\hline $\mathrm{H} 2 \mathrm{ZrF} 6$ & $6.1311 \mathrm{E}-32$ & $6.1311 \mathrm{E}-32$ & & \\
\hline$(\mathrm{HF}) 2$ & $1.2100 \mathrm{E}-19$ & 1.2100E-19 & & \\
\hline $\mathrm{HCl}$ & $7.6878 \mathrm{E}-13$ & $7.6878 \mathrm{E}-13$ & & \\
\hline $\mathrm{HF}$ & 1.3286E-09 & 1.3286E-09 & & \\
\hline $\mathrm{FeCl} 3$ & 8.2689E-18 & $8.2689 \mathrm{E}-18$ & & \\
\hline FeF3 & $9.7247 \mathrm{E}-25$ & $9.7247 \mathrm{E}-25$ & & \\
\hline $\mathrm{Fe}(\mathrm{OH}) 3$ & $1.6648 \mathrm{E}-19$ & $1.6648 \mathrm{E}-19$ & & \\
\hline $\mathrm{FePO} 4.2 \mathrm{H} 2 \mathrm{O}$ & 3.7956E-04 & & & 3.7956E-04 \\
\hline MgSiO2(OH)2 & $1.5740 \mathrm{E}-24$ & $1.5740 \mathrm{E}-24$ & & \\
\hline MgHPO4 & $5.9090 \mathrm{E}-11$ & $5.9090 \mathrm{E}-11$ & & \\
\hline MgSO4 & $1.3696 \mathrm{E}-19$ & 1.3696E-19 & & \\
\hline $\mathrm{Mn}(\mathrm{OH}) 2$ & $2.1464 \mathrm{E}-27$ & 2.1464E-27 & & \\
\hline $\mathrm{MnSO} 4$ & $1.1504 \mathrm{E}-19$ & $1.1504 \mathrm{E}-19$ & & \\
\hline H3PO4 & $1.0284 \mathrm{E}-03$ & $1.0284 \mathrm{E}-03$ & & \\
\hline KHSO4 & $1.2441 \mathrm{E}-20$ & $1.2441 \mathrm{E}-20$ & & \\
\hline $\mathrm{KCl}$ & 3.3788E-09 & 3.3788E-09 & & \\
\hline H4P2O7 & $1.5924 \mathrm{E}-06$ & 1.5924E-06 & & \\
\hline $\mathrm{SiCl} 4$ & $6.6029 E-68$ & $6.6029 E-68$ & & \\
\hline $\mathrm{NaB}(\mathrm{OH}) 4$ & $1.3957 \mathrm{E}-14$ & 1.3957E-14 & & \\
\hline $\mathrm{NaHSiO3}$ & $1.0277 \mathrm{E}-13$ & $1.0277 \mathrm{E}-13$ & & \\
\hline SO3 & 1.1095E-32 & 1.1095E-32 & & \\
\hline $\mathrm{H} 2 \mathrm{SO} 4$ & 8.0119E-29 & 8.0119E-29 & & \\
\hline HBF4 & $1.3168 \mathrm{E}-25$ & $1.3168 \mathrm{E}-25$ & & \\
\hline SiF4 & $2.1489 \mathrm{E}-24$ & $2.1489 \mathrm{E}-24$ & & \\
\hline $\mathrm{Zr}(\mathrm{OH}) 4$ & $3.7951 \mathrm{E}-15$ & $3.7951 \mathrm{E}-15$ & & \\
\hline $\mathrm{Zr}(\mathrm{SO} 4) 2.4 \mathrm{H} 2 \mathrm{O}$ & 8.2968E-05 & & & 8.2968E-05 \\
\hline $\mathrm{ZrCl} 4$ & 8.7399E-16 & 8.7399E-16 & & \\
\hline $\mathrm{AlOHCl}+1$ & $6.7880 \mathrm{E}-11$ & $6.7880 \mathrm{E}-11$ & & \\
\hline AlF2+1 & $1.5862 \mathrm{E}-08$ & $1.5862 \mathrm{E}-08$ & & \\
\hline $\mathrm{Al}(\mathrm{OH}) 2+1$ & 7.5893E-14 & 7.5893E-14 & & \\
\hline
\end{tabular}


Savannah River Technology Center

Immobilization Technology Section

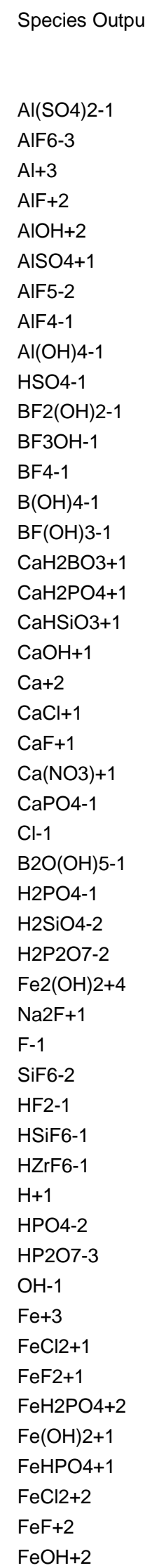

\begin{tabular}{|c|c|}
\hline $\begin{array}{l}\text { Slurry } \\
\text { (mole) }\end{array}$ & $\begin{array}{c}\text { Aqueous } \\
\text { (mole) }\end{array}$ \\
\hline 2.3819E-30 & $2.3819 \mathrm{E}-30$ \\
\hline $1.2701 \mathrm{E}-29$ & $1.2701 \mathrm{E}-29$ \\
\hline $1.0572 \mathrm{E}-03$ & $1.0572 \mathrm{E}-03$ \\
\hline 3.0871E-05 & $3.0871 \mathrm{E}-05$ \\
\hline 3.9183E-09 & 3.9183E-09 \\
\hline 3.7907E-17 & 3.7907E-17 \\
\hline 1.4928E-23 & $1.4928 \mathrm{E}-23$ \\
\hline 3.8938E-18 & $3.8938 \mathrm{E}-18$ \\
\hline 7.5667E-24 & 7.5667E-24 \\
\hline 2.6371E-17 & $2.6371 \mathrm{E}-17$ \\
\hline $1.7761 \mathrm{E}-14$ & $1.7761 \mathrm{E}-14$ \\
\hline 2.9534E-18 & $2.9534 \mathrm{E}-18$ \\
\hline $2.3811 \mathrm{E}-21$ & $2.3811 \mathrm{E}-21$ \\
\hline 3.1887E-13 & $3.1887 \mathrm{E}-13$ \\
\hline 1.2777E-13 & $1.2777 \mathrm{E}-13$ \\
\hline $1.7721 \mathrm{E}-14$ & $1.7721 \mathrm{E}-14$ \\
\hline 8.4805E-06 & 8.4805E-06 \\
\hline $2.1004 \mathrm{E}-16$ & $2.1004 \mathrm{E}-16$ \\
\hline 4.9749E-18 & $4.9749 \mathrm{E}-18$ \\
\hline 3.3124E-05 & 3.3124E-05 \\
\hline 7.4423E-13 & $7.4423 \mathrm{E}-13$ \\
\hline 4.0599E-15 & $4.0599 \mathrm{E}-15$ \\
\hline 1.4706E-05 & $1.4706 \mathrm{E}-05$ \\
\hline 3.4087E-18 & $3.4087 \mathrm{E}-18$ \\
\hline $1.6801 \mathrm{E}-05$ & $1.6801 \mathrm{E}-05$ \\
\hline $6.2387 \mathrm{E}-15$ & $6.2387 \mathrm{E}-15$ \\
\hline 1.3235E-04 & 1.3235E-04 \\
\hline 1.3096E-25 & $1.3096 \mathrm{E}-25$ \\
\hline 4.5734E-07 & $4.5734 \mathrm{E}-07$ \\
\hline $6.2324 \mathrm{E}-19$ & $6.2324 \mathrm{E}-19$ \\
\hline $1.7689 \mathrm{E}-14$ & $1.7689 \mathrm{E}-14$ \\
\hline $5.1721 \mathrm{E}-11$ & $5.1721 \mathrm{E}-11$ \\
\hline 6.2916E-30 & $6.2916 \mathrm{E}-30$ \\
\hline $1.0454 \mathrm{E}-17$ & $1.0454 \mathrm{E}-17$ \\
\hline 7.2698E-30 & $7.2698 \mathrm{E}-30$ \\
\hline $1.4896 \mathrm{E}-30$ & $1.4896 \mathrm{E}-30$ \\
\hline 3.1263E-04 & 3.1263E-04 \\
\hline 1.8602E-09 & $1.8602 \mathrm{E}-09$ \\
\hline 1.8907E-11 & $1.8907 \mathrm{E}-11$ \\
\hline $1.6448 \mathrm{E}-16$ & $1.6448 \mathrm{E}-16$ \\
\hline 4.2178E-09 & $4.2178 \mathrm{E}-09$ \\
\hline $3.5794 \mathrm{E}-14$ & $3.5794 \mathrm{E}-14$ \\
\hline 9.8723E-19 & $9.8723 \mathrm{E}-19$ \\
\hline 4.3778E-07 & 4.3778E-07 \\
\hline 4.0142E-15 & $4.0142 \mathrm{E}-15$ \\
\hline 8.2178E-09 & $8.2178 \mathrm{E}-09$ \\
\hline $5.9033 \mathrm{E}-12$ & 5.9033E-12 \\
\hline $9.5858 \mathrm{E}-14$ & $9.5858 \mathrm{E}-14$ \\
\hline 4.8243E-11 & $4.8243 \mathrm{E}-11$ \\
\hline
\end{tabular}

WSRC-TR-2002-00436

Page 32 of 34

November 11, 2002

Vapor Solid

(mole) (mole) 
Savannah River Technology Center

Immobilization Technology Section

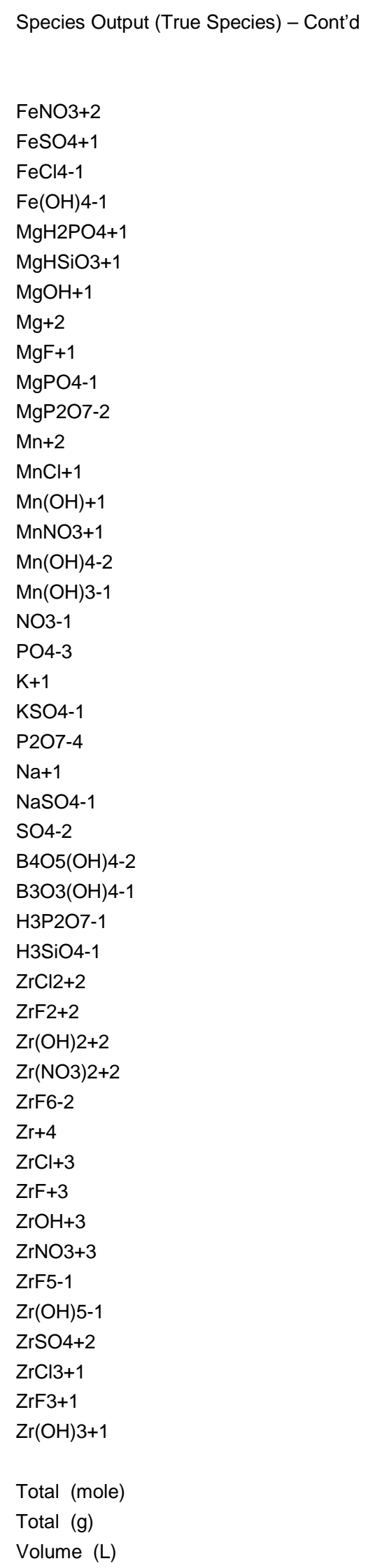

$\begin{array}{cccc}\text { Slurry } & \text { Aqueous } & \text { Vapor } & \text { Solid } \\ (\text { mole }) & (\text { mole }) & \text { (mole) } & \text { (mole) }\end{array}$

1.1654E-10 1.1654E-10

$5.8545 \mathrm{E}-23 \quad 5.8545 \mathrm{E}-23$

$2.6408 \mathrm{E}-21 \quad 2.6408 \mathrm{E}-21$

$1.2781 \mathrm{E}-27 \quad 1.2781 \mathrm{E}-27$

9.4977E-06 9.4977E-06

3.3819E-16 3.3819E-16

4.1537E-17 4.1537E-17

7.8294E-06 7.8294E-06

8.0937E-16 8.0937E-16

$4.1728 \mathrm{E}-18 \quad 4.1728 \mathrm{E}-18$

$2.1529 \mathrm{E}-16 \quad 2.1529 \mathrm{E}-16$

9.0383E-06 9.0383E-06

3.1988E-08 3.1988E-08

3.5719E-16 3.5719E-16

2.2013E-06 2.2013E-06

6.5826E-50 6.5826E-50

$1.6901 \mathrm{E}-38 \quad 1.6901 \mathrm{E}-38$

5.5547E-03 5.5547E-03

$1.0827 \mathrm{E}-19 \quad 1.0827 \mathrm{E}-19$

2.0667E-04 2.0667E-04

7.8076E-19 7.8076E-19

3.0394E-18 3.0394E-18

8.4341E-04 8.4341E-04

$1.1769 \mathrm{E}-17 \quad 1.1769 \mathrm{E}-17$

4.8552E-17 4.8552E-17

$1.2416 \mathrm{E}-22 \quad 1.2416 \mathrm{E}-22$

9.9604E-15 9.9604E-15

6.4709E-07 6.4709E-07

$1.1835 \mathrm{E}-14 \quad 1.1835 \mathrm{E}-14$

$3.4011 \mathrm{E}-10 \quad 3.4011 \mathrm{E}-10$

5.2382E-07 5.2382E-07

$1.7666 \mathrm{E}-08 \quad 1.7666 \mathrm{E}-08$

1.1527E-12 1.1527E-12

$3.7418 \mathrm{E}-28 \quad 3.7418 \mathrm{E}-28$

$2.0275 \mathrm{E}-05 \quad 2.0275 \mathrm{E}-05$

$9.2286 \mathrm{E}-07 \quad 9.2286 \mathrm{E}-07$

2.3906E-04 2.3906E-04

5.7154E-05 5.7154E-05

1.3187E-12 1.3187E-12

1.6273E-24 1.6273E-24

4.6430E-20 4.6430E-20

2.0319E-22 2.0319E-22

$3.1468 \mathrm{E}-13 \quad 3.1468 \mathrm{E}-13$

5.8508E-08 5.8508E-08

2.8654E-11 2.8654E-11

1.2631E-01 1.2709E-01

1.9914E-03

1.9543E-01

$2.9057 \mathrm{E}+00 \quad 2.7102 \mathrm{E}+00$

2.3982E-03 2.3231E-03 
Savannah River Technology Center Immobilization Technology Section

sity $(\mathrm{g} / \mathrm{ml})$

Enthalpy (cal)

\section{Additional Stream}

\section{Properties}

Temperature (oC)

Pressure (atm)

$\mathrm{pH}$

lonic Strength (molal)

Osmotic Pressure (atm)

WaterActivity

Electrical Cond, specific, (1/ohm)

Electrical Cond, molar, (cm2/ohm-mol)

Viscosity, absolute (cP)

Viscosity, relative $(\mathrm{cP} / \mathrm{cP} \mathrm{H} 2 \mathrm{O})$

WSRC-TR-2002-00436

Page 34 of 34

November 11, 2002

Slurry
(mole)

Aqueous

(mole)

$1.1666 \mathrm{E}+00$

$-9.5402 E+03$

$-8.9648 E+03$
Solid

(mole)

$2.6029 \mathrm{E}+00$

$-5.7536 \mathrm{E}+02$
$2.5000 \mathrm{E}+01$

$1.0000 \mathrm{E}+00$

$1.0595 \mathrm{E}+00$

$4.7314 \mathrm{E}+00$

$9.0444 \mathrm{E}+01$

9.3466E-01

7.1116E-02

$2.4218 \mathrm{E}+01$

$1.5064 \mathrm{E}+00$

1.6912E+00 